\title{
How Audience Members Envision New Testament Characters: Mental Character Models, Blending, and the Reception of Luke 1:5-2:52
}

\author{
Kirsten Marie Hartvigsen \\ Department of Teacher Education and School Research, University of Oslo, \\ Oslo, Norway \\ k.m.hartvigsen@ils.uio.no
}

\begin{abstract}
In the Gospel of Luke 1-2, the narrator focuses on two couples and their (future) sons. The plot of the narrative emphasizes the main characteristics of the characters, which in turn accentuate important characteristics of God. Audience members construct these characters like real-life persons based on the discourse aspect (textual features which indicate character traits, plots, focalization, etc.) and the suggestion aspect (memories, emotions, schemata that are activated or primed, etc.). In this article, the construction of characters is analyzed with insights into mental character models and social schemata. The linear presentation of information in orally performed narratives structures the first part of the analysis. The latter part draws on conceptual blending theory to explore how the character of God is constructed based on selected information projected from the utterances of the other characters to the blended space.
\end{abstract}

\section{Keywords}

mental character models - conceptual blending theory - Luke 1-2 


\section{Introduction}

Theories of literary characters and characterization have usually focused on questions such as the following: Are characters people or words? ${ }^{1}$ How are characters constructed from the text? How can characters be classified? Biblical scholars interested in characters and characterization have traditionally drawn on the insights provided by Edward Morgan Forster, Seymour Chatman, Joseph Ewen, and Shlomith Rimmon-Kenan, among others. ${ }^{2}$ However, there are important limitations to these theories and approaches. Most approaches ${ }^{3}$ employed in this article fall within the field of inquiry David Herman labeled cognitive narratology, ${ }^{4}$ which is a subdomain of postclassical

1 The debate over this question is discussed by S. Rimmon-Kenan, Narrative Fiction: Contemporary Poetics (New Accents; London: Routledge, 1996), 31-34; F. Jannidis, "Character," in P. Hünn et al. (eds.), Handbook of Narratology 1 (Berlin: De Gruyter, 2014), 30-45 (32).

2 E.M. Forster's classification of characters as "flat" or "round," in Aspects of the Novel (London: Edward Arnold, 1927), 93-106, has been the most influential. See, for example, M.A. Powell, What is Narrative Criticism? A New Approach to the Bible (London: SPCK, 1993), 55; D. Rhoads, J. Dewey, and D. Michie, Mark as Story: An Introduction to the Narrative of a Gospel (2nd edn; Minneapolis: Fortress Press, 1999), 102. Chatman's description of a character as a "paradigm of traits" in S. Chatman, Story and Discourse: Narrative Structure in Fiction and Film (Ithaca and London: Cornell University Press, 1978), 126, has been employed by Powell, Narrative Criticism, 54; Rhoads, Dewey, and Michie, Mark as Story, 102. Through the work of RimmonKenan, Narrative Fiction, 41-42, J. Ewen's model of character-classification consisting of three axes (complexity, development, and penetration into the inner life), articulated in "The Theory of Character in Narrative Fiction," (in Hebrew) Hasifrut 3 (1971): 1-30; English abstract, i-ii, has reached biblical scholarship. See, for example, C. Bennema, "Character Reconstruction in the New Testament (1): The Theory," The Expository Times 127 (2016): 365-374 (369).

3 The exception is conceptual blending theory, which belongs to the realm of cognitive linguistics. In this article, blending theory is utilized to illuminate the dynamics and effects of the interrelated perspectives of the characters in Luke $1-2$.

4 D. Herman, "Cognitive Narratology (revised version; uploaded 22 September 2013)," in P. Hühn, J.C. Meister, J. Pier, and W. Schmid (eds.), The Living Handbook of Narratology (Hamburg: Hamburg University Press, 2013) https://www.lhn.uni-hamburg.de/node/38.html. The term has been used since 1997, but in literary studies, questions and concerns subsumed under this term can be traced to earlier research, for instance, on reader response and issues of reception. See W. Iser, The Implied Reader: Patterns of Communication in Prose Fiction from Bunyan to Beckett (Baltimore: Johns Hopkins University Press, 1974); H.R. Jauss, Toward an Aesthetic of Reception (Minneapolis: University of Minnesota Press, 1982). Among the focal areas of cognitive narratology are mental processes that support inferences about the story world (R.J. Gerrig, Experiencing Narrative Worlds: On the Psychological Activities of Reading [New Haven: Yale University Press, 1993], cognitive reception theories (R.J. Gerrig, Narrative Worlds), empirical studies (M. Bortolussi and P. Dixon, Psychonarratology: Foundations for the Empirical Study of Literary Response [Cambridge: Cambridge University Press, 2003]), transmedial studies (M.-L. Ryan, Narrative as Virtual Reality Immersion and Interactivity in Literature and Electronic Media [Baltimore and London: Johns Hopkins University Press, 
narratology. 5 These approaches draw on, extend, refine, and transcend those employed by representatives of classical narratology. A central question of cognitive narratology is how narrative experiences arise when stories and the mental states and processes of interpreters intertwine. ${ }^{6}$ The next sections provide an initial answer to this question with emphasis on how readers and listeners construct the narrative world and its inhabitants. Due to the scope

2001]), characterization (R. Schneider, "Toward a Cognitive Theory of Literary Character: The Dynamics of Mental-Model Construction," Style 35 [2001]: 607-639.), and studies on emotions (P.C. Hogan, The Mind and Its Stories: Narrative Universals and Human Emotion; Studies in Emotion and Social Interaction [Cambridge: Cambridge University Press, 2003]; idem, Cognitive Science, Literature, and the Arts: A Guide for Humanists [New York: Routledge, 2003]; idem, Affective Narratology: The Emotional Structure of Stories [Lincoln: University of Nebraska Press, 2011]; K. Oatley, Best Laid Schemes: The Psychology of Emotions, Studies in Emotion and Social Interaction [Cambridge: Cambridge University Press, 1992]; idem, "Emotions and the Story Worlds of Fiction," in M.C. Green, J.J. Strange and T.C. Brock [eds], Narrative Impact: Social and Cognitive Foundations [New York: Psychology Press, 2004]). For these and further areas and representatives, see Herman, "Cognitive Narratology." Michal Beth Dinkler explores the relations between literary theory and New Testament scholarship in Literary Theory and the New Testament (The Anchor Yale Bible Reference Library; New Haven and London: Yale University Press, 2019). By merely mentioning cognitive approaches in passing, Dinkler practically overlooks the cognitive turn in both fields. On the cognitive turn in the study of the New Testament, see I. Czachesz, Cognitive Science and the New Testament: A New Approach to Early Christian Research (Oxford: Oxford University Press, 2017).

5 On postclassical narratology, see J. Alber and M. Fludernik (eds.), Postclassical Narratology: Approaches and Analyses (Columbus: Ohio State University Press, 2010). Some strands of postclassical narratology can be perceived as an extension and refinement of classical narratology, as represented by Roland Barthes, Tzvetan Todorov, Gerard Genette, A. J. Greimas, Claude Bremond, and later figurants, such as Mike Bal and Seymour Chatman. See G. Prince, "Classical and/or Postclassical Narratology," L'Esprit Créateur 48 (2008) 115-123 (115). Others transcend the assumptions and axioms of the classical paradigm, for example, J. Alber and M. Fludernik, "Introduction," in J. Alber and M. Fludernik, Postclassical Narratology, 1-31 (3).

6 Herman, "Cognitive Narratology." Since it is impossible to carry out empirical research on the mental processes of ancient audiences, the mental processes involved in the construction of the Lukan world, including its characters, must be carried out by modern scholars (like other interpretations of ancient texts). However, current empirical research and theoretical insights from cognitive narratology facilitate reflections on the mechanics of these mental processes. Because cognitive scientists study the minds of contemporary people, one could argue that their results cannot inform reflections on the mental processes of ancient audiences. However, the pace of evolution suggests that the basic structures and mechanisms of ancient minds were not different from contemporary minds: "Since we share the anatomy of our brains and bodies with ancients, we can understand their thoughts and feelings by studying how brain, body, thoughts, and feelings are related in general" (Czachesz, Cognitive Science, 9). See also M.R. Whitenton, Configuring Nicodemus: An Interdisciplinary Approach to Complex Characterization (London: T\&T Clark, 2019), 11-16. 
of the article, only selected aspects of these fields are presented and subsequently used in the analysis. ${ }^{7}$

The nativity stories in the Gospel of Luke 1-2 present Zechariah, Elizabeth, Gabriel, Mary, Joseph, John, Jesus, the shepherds, Simeon, and Anna and their main characteristics. The focus of these stories is on Zechariah, Elizabeth, Mary, and to some extent Joseph, but the large gallery of characters collectively illustrates different responses to divine intervention. The lives of these characters are interwoven, and they are portrayed in ways that highlight their social roles, functional group roles, key traits, and actions. The construction of mental character models is important to elucidate how audience members interpret the nativity stories, ${ }^{8}$ and this article takes the linear disclosure of information into account when this construction is investigated. However, as

7 J. Rüggemeier and E.E. Shively, "Introduction: Towards a Cognitive Theory of New Testament Characters: Methodology, Problems, and Desiderata" Biblical Interpretation 4-5 (2021): [403-429] provide an overview of the field. See also Whitenton Configuring Nicodemus; K.M. Hartvigsen, Prepare the Way of the Lord: Towards a Cognitive Poetic Analysis of Audience Involvement with Characters and Events in the Markan World (BZNW 180; Berlin: De Gruyter, 2012).

8 Similar to the other gospels, the Gospel of Luke does not name its author and it does not provide specific clues about its earliest text-external audience. The lack of text-external information makes it impossible to pinpoint the location of a specific ancient audience. Richard Bauckham argues that the gospels were written for "any church" in which Greek was understood. R. Bauckham, "For Whom were Gospels Written?" in R. Bauckham (ed.), The Gospels for All Christians: Rethinking the Gospel Audiences (Grand Rapids and Cambridge: Eerdmans, 1998), 9-48. John T. Carroll suggests that, although the specific location of Luke's audience within the Roman Empire is unknown, it was likely an urban center. J.T. Carroll, Luke: A Commentary (The New Testament Library; Louisville: Westminster John Knox Press, 2012), 3-4. Esa Autero proposes that this community was largely Gentile. E.J. Autero, "Social Status in Luke's Infancy Narrative: Zechariah the Priest," Biblical Theology Bulletin 41 (2011): 36-45 (39). According to Amy-jill Levine and Ben Witherington, Theophilus (lover of God) may represent the intended or ideal audience of the Gospel of Luke. A.-J. Levine and B. Witherington III, The Gospel of Luke (New Cambridge Bible Commentary; Cambridge: Cambridge University Press, 2018), 8-9. For the problems of constructing a homogeneous implied audience, see Hartvigsen, Prepare the Way, 13. Against this backdrop, a heterogeneous audience is assumed in this article. What we do know is that the gospels were most likely read aloud or orally performed. R.A. Burridge, "About People, by People, for People: Gospel Genre and Audiences," in Bauckham, Gospels, 113-145; E. Struthers Malbon, Hearing Mark: A Listener's Guide (Harrisburg: Trinity Press International, 2002); A.C. Wire, The Case for Mark Composed in Performance (Biblical Performance Criticism Series 3; Eugene: Cascade Books, 2011); W. Shiner, Proclaiming the Gospel: First-Century Performance of Mark (Harrisburg: Trinity Press International, 2003). Even though the literature subsumed under the term cognitive narratology focuses on readers, insights from this literature can illuminate the mental processes experienced by ancient audience members, with some modifications (Hartvigsen Prepare the Way, 36-40). Hartvigsen draws on Bortolussi and 
I argue in the final section of this article, one could also claim that the portrayals of these characters and the character constellations ultimately highlight important characteristics of God. The main point of this article is not necessarily to create a new and revolutionary interpretation, but to supply evidence that explains and supports the interpretations that are presented. ${ }^{9}$

\section{Theoretical Backdrop}

\section{Construction of Narrative Worlds}

During the reading or listening process, mental representations of the narrative are constructed, which consist of the following four aspects: ${ }^{10}$ discourse, suggestion, realization, and story aspects. ${ }^{11}$ In this context, I will draw attention to how the realization aspect (i.e., the narrative world as perceived by the reader or listener) is constructed based on the features constituting the discourse aspect (i.e., textual features which indicate character traits, plots, focalization, etc. $)^{12}$ and the suggestion aspect (i.e., knowledge, memories, emotions, and thoughts that are brought to mind by the discourse aspect)..$^{13}$

Dixon's work on narrative levels (Psychonarratology, 30), which indicates that readers blur these levels, that is, "readers process the narrator as if they were communicating with such an individual in conversation." During an oral performance of the gospel, the performer embodies the narrator, and the audience will treat her or him as a conversational participant (Hartvigsen, Prepare the Way, 36-40).

9 On this principle, see J. Culpeper, "Reflections on a Cognitive Stylistic Approach to Characterization," in G. Brône and J. Vandaele (eds.), Cognitive Poetics: Goals, Gains and Gap (Applications of Cognitive Linguistics, 10; Berlin: De Gruyter, 2009), 125-159; here, 126.

10 Oatley, "Story Worlds," 44-59; Hartvigsen, Prepare the Way, 35-47. The model consisting of four aspects contrasts Chatman's familiar model of two aspects: story and discourse. S. Chatman, Story and Discourse. The suggestion aspect facilitates explanations of personal facets of the enactment of narratives. Because the discourse aspect informs the realization aspect, the realization aspect comes close to being an aspect constructed by a generalized implied reader (Oatley, "Story Worlds," 44-45), but it also reflects the associations recalled by the suggestion aspect (Oatley, "Conversation," 110).

11 The story aspect is the events in the story world, and it is a creation of the author. Oatley, "Conversation," 105 .

12 On these features, see also Rimmon-Kenan, Narrative Fiction.

13 For similar insights, see P. Stockwell, Cognitive Poetics: An Introduction (London and New York: Routledge, 2002), 91; M. Hartner, "Constructing Literary Character and Perspective: An Approach from Psychology and Blending Theory," in R. Schneider and M. Hartner 
The contributions of readers and listeners to the construction of the narrative world are essential because an author cannot provide all information about the events, characters, and environments that are present in the narrative. Readers and listeners thus fill in the gaps created by the textual clues by inferring knowledge based on the information they have stored in their longterm memory, for instance in schemata. ${ }^{14}$ Because they may have different experiences and knowledge, ${ }^{15}$ different types of knowledge may be primed or activated during the reading and listening process. ${ }^{16}$ Because of this process, each reader and listener may construct slightly different mental representations of the characters, events, and settings that constitute the narrative world, which in turn may result in different interpretations. ${ }^{17}$

\section{Construction of Characters}

This article focuses on the construction of one aspect of the narrative world; that is, characters. ${ }^{18}$ Approaches labeled psychonarratology, cognitive poetics, cognitive stylistics, and cognitive esthetics of reception emphasize the mental

(eds.), Blending and the Study of Narrative: Approaches and Applications (Narratologia: Contributions to Narrative Theory, 34; Berlin: De Gruyter, 2012): 85-120 (89-9o).

14 Hogan, Cognitive Science, 117; Culpeper, "Reflections," 128ff. This model thus further develops insights from theories of gap-filling, as presented by Wolfgang Iser, The Act of Reading: A Theory of Aesthetic Response (Baltimore: Johns Hopkins University Press, 1978). According to empirical research, readers do not make inferences about all aspects of the narrative world. Some inferences are generated on-line, whereas others are constructed off-line, if at all. A.C. Graesser, M. Singer, and T. Trabasso, "Constructing Inferences During Narrative Text Comprehension," Psychological Review 101 (1994): 371-395 (371-372, 375). On-line means "during the course of comprehension," whereas off-line means "generated during a later retrieval task but not during comprehension" (Graesser et al., "Constructing Inferences," 371). U. Margolin, "Comments on Culpeper," in G. Brône and J. Vandaele, Cognitive Poetics, 161-165 (163); Hartvigsen, Prepare the Way, 40-42.

16 Activation, that is, recall of an element, may prime other associated elements. Primed elements are put in a state of low-level activation, which means that they are more easily activated than latent elements. Hogan, Mind, 52; idem, Cognitive Science, 156-158; B. Snyder, Music and Memory: An Introduction (Cambridge: MIT Press, 200o), 48, 262.

17 Ancient and modern audiences are located in different historical and cultural contexts. In order for modern scholars to approximate ancient mental representations of the Lukan world and its characters, insights from cognitive approaches on mental processes must be supplemented with knowledge from other fields of research, such as sociology, anthropology, and history.

18 Whereas some traditional approaches to characters perceive them as real people with personalities that can explain their actions and emotions, others regard them as aggregates of textual signs that the reader must assemble. These two approaches correspond to the mimetic and synthetic aspects presented by James Phelan in Reading People, Reading Plots. Character, Progression, and the Interpretation of Narrative (Chicago: The University of Chicago Press, 1989). In recent articles, M.B. Dinkler attempts to bridge the two approaches to 
processes through which readers construct characters, ${ }^{19}$ but the main principles also apply to the mental processes of listeners: ${ }^{20}$ The clues provided by the written text or performance, such as what a character does or says, trait descriptions that the extradiegetic narrator ${ }^{21}$ or other characters attribute to a character, and indications of character change, constitute the point of departure of readers and listeners. They then use their previous knowledge and beliefs about real people, their personalities, and how they behave to create consistent characters. ${ }^{22}$ In the words of Bortolussi and Dixon, "[r]eaders by default assume that they will encounter real-life characters and make a concerted effort to fill in the schematic gaps to produce human-like constructs." 23 But how do readers and listeners fill in these gaps and how do they construct what could be labeled mental character models? ${ }^{24}$ Below, complementary insights from Ralf Schneider and Jonathan Culpeper elucidate these topics. Their insights are supplemented by Bosak's insights into types of social roles.

characters, whereas H.M. Cocksworth emphasizes Phelan's third aspect, that is, the thematic. See M.B. Dinkler, "Building Character on the Road to Emmaus: Lukan Characterization in Contemporary Literary perspective," JBL 136 (2017): 687-706; H.M. Cocksworth, "Zechariah and Gabriel as Thematic Characters: A Narratological Reading of the Beginning of Luke's Gospel (Luke 1:8-20)," in F. Dicken and J. Snyder (eds.), Characters and Characterization in Luke-Acts (London: Bloomsbury T\&T Clark, 2016): 41-54.

19 In a recent book on literary characters, Ibrahim Taha explores the process of constructing characters by means of blending theory. He presents a conceptual integration network that illustrates the blending process from two perspectives simultaneously (i.e., from the perspectives of the author and the reader). I. Taha, Heroizability: An Anthroposemiotic Theory of Literary Characters (Semiotics, Communication and Cognition, 16; Berlin: De Gruyter, 2015), 72. See also the discourse, suggestion, and realization aspects above, where the realization aspect can be perceived as a blend.

20 The scope of the article does not allow for detailed theoretical elaboration of how a performance situation differs from a silent reading of the gospels. For information about how an oral performance influences involvement with characters and events, see Hartvigsen, Prepare the Way. On characters, see Whitenton, Configuring Nicodemus.

21 The extradiegetic narrator narrates the story from a position outside, or above, the narrative world of a particular text. See Rimmon-Kenan, Narrative Fiction, 91-95. The narrator of the Gospel of Luke is an extradiegetic narrator.

22 Bortolussi and Dixon, Psychonarratology, 149-164; Schneider, "Literary Character," 608.

23 Bortolussi and Dixon, Psychonarratology, 152-153.

24 Ralf Schneider defines mental character model as an "entity that 'collects' all information from textual and memory sources, including evaluations." R. Schneider, "The Cognitive Theory of Character Reception: An Updated Proposal," Anglistik: International Journal of English Studies 24 (2013): 117-134; here, 122. Schneider perceives the concept mental character model as a container metaphor, but he also suggests that "we perhaps need to understand the mental model as a co-activation of particular neural networks" (122, note 22). 
According to Schneider,

Information from various sources, both textual and reader-centered, feed[s] into the construction of mental character models. Text understanding always combines top-down processing, in which the reader's pre-stored knowledge structures are directly activated to incorporate new items of information, and bottom-up processing, in which bits of textual information are kept in working memory separately and integrated into an overall representation at a later point in time. Top-down and bottom-up processing continually interact in the reading process on all levels: from the decoding of the graphic signs to the understanding of words, sentence structure and the contents of longer sections. ${ }^{25}$

The construction of a relatively coherent and comprehensive mental representation of a particular character is thus a dynamic process that takes place in working memory when a narrative is read or heard. During this process, readers and listeners continually update the mental character model by integrating incoming textual data with their personal knowledge structures that are brought out of long-term memory.

The mental character model may integrate information about physical appearance and abstract character traits that may indicate intellectual capacity and emotional disposition, specific utterances, and nonverbal behavior. ${ }^{26}$ During the reading or listening process, the following elements constituting the discourse aspect may suggest that new elements should be integrated into the mental character model: a) direct definitions of a character trait or descriptions of such a trait, verbal and non-verbal behavior, external appearance, and body language communicated by the narrator, the character, or other characters; b) presentations of a character's consciousness; and c) character traits inferred based on the environment. ${ }^{27}$ When it comes to behavior, Culpeper suggests that behavior may be internally driven, which may indicate the personality of the person who performs the action, or externally driven, where the action may rather reflect the context of the actions. Only the former directly reflects a character trait. ${ }^{28}$ Moreover, a character may be introduced with textual cues that may activate the readers' or listeners' knowledge of genre

25 Schneider, "Literary Character," 611.

26 Schneider, "Literary Character," 610-611.

27 Schneider, "Literary Character," 611; Rimmon-Kenan, Narrative Fiction, 59-70.

28 Culpeper, "Reflections," 140-141. 
schemata (literary categorization) and social schemata. ${ }^{29}$ These schemata may enable them to integrate data into coherent patterns, understand a particular situation, and make inferences about a character's behavior, inclinations, and so on.

Schemata refer to integrated portions of knowledge about the world, people, events, and actions, and they constitute the clusters of intersecting concepts that comprise the structure of long-term memory. ${ }^{30}$ Social schemata are constituted from knowledge about people, and this knowledge may explain the readers' and listeners' expectations about a character. Regarding the Gospel of Luke $1-2$, the way textual cues may activate social and literary schemata is of particular importance.

Culpeper ${ }^{31}$ presents three groupings of social schemata that can be located at three levels of generality, and he focuses on the second category:

1. Personal categories about the individual person (e.g., preferences, interests, traits, goals)

2. Social-role categories about one's station and the properties normally associated with it (e.g., kinship roles, occupational roles, relational roles)

3. Group-membership categories (e.g., gender roles, race, class, age, nationality, religion)

Culpeper's groupings can be extended based on insights into different types of social roles. Bosak ${ }^{32}$ differentiates between basic roles, "based on membership in general social categories (e.g., gender, age, ethnicity)," position or status roles, based on occupations and family relationships, "functional group roles, like 'mediator,' 'counselor,' and 'devil's advocate,"'33 and "value roles, such as 'saint,' 'hero,' and 'villain."'34 Whereas the first two types of roles correspond to Culpeper's second and third categories, the final two are not mentioned by Culpeper. These two role types can be placed between Culpeper's first and second categories. The latter types of roles are of importance in Luke 1-2.

When readers and listeners can assimilate new information into an existing social schema, schematic categorization occurs, which is a top-down process

29 Schneider, "Literary Character," 611-612, 619.

30 Culpeper, "Reflections," 128; Margolin, "Comments," 161.

31 Culpeper, "Reflections," 134. See also Whitenton, Configuring Nicodemus, 33.

32 J. Bosak, "Social Roles," in T. Shackelford and V. Weekes-Shackelford (eds.), Encyclopedia of Evolutionary Psychological Science (Cham: Springer, 2018) https://doi. org/10.1007/978-3-319-16999-6_2469-1.

33 These roles "develop informally as individuals adopt situational identities during social interaction in a group setting." J. Bosak, "Social Roles," 1.

34 These roles "emerge in the context of very positively or negatively valued behavior" (Bosak, "Social Roles," 1). 
that takes precedence over bottom-up processes because it requires less effort. If readers and listeners are unable to assimilate the information into available social categories, they must employ bottom-up processes that require more cognitive effort. ${ }^{35}$ According to Schneider, bottom-up and top-down processes result in the construction of two different types of mental character models. ${ }^{36}$ He labels the top-down approach categorization and the bottom-up approach personalization. ${ }^{37}$ Schneider also suggests that models based on categorization can reach the stage of individuation. ${ }^{38}$

Culpeper presents a four-stage process that sheds further light on how readers and listeners process characters. ${ }^{39}$ Whereas the first three stages could be subsumed under the label categorization, the fourth stage constitutes personalization. ${ }^{40}$

1. Initial categorization

2. Confirmatory categorization (The new information fits the preliminary categorization.)

3. Recategorization (The new information does not match the preliminary categorization, but it is categorizable through another schema or a subschema. This may raise the awareness of readers and listeners. $)^{41}$

4. Piecemeal integration (The information does not fit any category. The attributes of a character are added up to form an impression. $)^{42}$

The construction of a mental character model may start as soon as identifying features such as a personal pronoun, name, or social role are mentioned. The model remains in working memory as long as readers and listeners are provided with new information about the character or focus on this character. The model may be reactivated and updated at a later point. ${ }^{43}$

Regarding biblical texts, the construction of mental character models during the reading or listening process is complicated. Because the original communication situations are no longer available for empirical research, the mental character models of biblical characters are created by contemporary scholars

35 Culpeper, "Reflections," $135^{-138 .}$

36 Culpeper, "Reflections," 122.

37 This model has some similarities to Forster's model of "flat" and "round" characters (Schneider, "Character Reception," 123).

38 Schneider, "Character Reception," 123.

39 Culpeper, "Reflections," 136.

40 See also R. Schneider, "Literary Character," 616-626. On the relationship between this model and Forster's model of "flat" and "round" characters (with examples), see Culpeper, "Reflections," $136-137$.

41 Schneider "Character Reception," 125 focuses on de-categorization.

42 Schneider also argues that a personalized character model can become de-personalized.

43 Schneider, "Literary Character," 610-611. 
who do not have firsthand knowledge about the ancient text-external world, including social schemata. ${ }^{44}$ Thus, our categorizations and character expectations may only approximate those of ancient audiences.

\section{Characters and Emotions}

According to Marcus Hartner, construction of mental character models "goes beyond a discussion of frames, scripts and schemata, bottom-up and top-down processing, or the activation of background knowledge [...] but is particularly based on the cognitive ability to mentally adopt or simulate alternative points of view."45 This claim is related to an important aspect of how readers and listeners become involved with characters and how this involvement elicits their emotions. ${ }^{46}$ Elicitation of emotions can be explained in different ways. The suggestion aspect mentioned above indicates that emotions could be elicited by New Testament narratives because the characters, events, and environments portrayed in these narratives prime or activate memories and emotions that readers and listeners have experienced previously. When they construct the narrative world (the realization aspect), including its characters, fragmentary memories may be integrated into these mental constructions and these memories may elicit emotions. ${ }^{47}$ This approach primarily explains why people experience different emotions when they read or hear a text. ${ }^{48}$

Another way of explaining emotions is by means of appraisal theory. According to this theory, emotions are generally elicited based on evaluations of an event and of how it may affect one's plans and goals. For instance, are the consequences of the event positive or negative and how likely are they to occur? If a situation arises that is expected to change a person's previous evaluations of goal achievement, emotions are elicited ${ }^{49}$ Regarding literature, Oatley argues that emotions are elicited in this manner when readers identify

44 Hartvigsen, Prepare the Way, 15; C. Bennema, A Theory of Character in New Testament Narrative (Minneapolis: Fortress Press, 2014), 62-67. According to Schneider, "[r]eaders from a later period than the text's origin will have to rely heavily on text-specific information unless they have acquired socio-historical knowledge that turns them into well-informed readers who are able to activate quasi-social categorizations quickly." Schneider, "Literary Character," 620.

45 Hartner, "Constructing," 91.

46 Hartvigsen, Prepare the Way, 68-82

47 Hogan, Cognitive Science, 162.

48 Hogan, Cognitive Science, 185.

49 Hogan, Cognitive Science, 144-145; idem, Affective Narratology, 42-44. 
with the protagonist, adopt her or his plans and goals, and simulate the events that occur in the narrative world according to the character's plans and goals. ${ }^{50}$ In that case, the emotions of the reader will mirror those of the character. ${ }^{51}$ This approach to emotions primarily explains why different readers and listeners experience similar emotions. However, according to Ed Tan, viewers at the movie theater may also envision their own preferred ending of the movie. ${ }^{52}$ Transferred to literature, the eliciting condition of the readers' emotions is constituted by their preferred outcomes or goals for the protagonist or other characters. In this case, the goal may not necessarily be shared by the character and thus the emotions of the reader and character may not coincide. ${ }^{53}$ According to Hogan, the approaches to emotions presented in this section may be synthesized. ${ }^{4}$

Elements constituting the Lukan nativity stories may elicit the emotions of audience members in different ways. However, the difficulties involved in exploring the various types of individual emotions that may be elicited by the suggestion aspect indicate that emphasis should be on emotions that can be explained by means of appraisal theory. In other words, because of the difficulties involved in exploring emotional responses based on individual readers' or listeners' previous experiences that may be elicited by the text, it is preferable to study the emotions that mirror those the characters themselves may be perceived as feeling based on the outworking of their plans and goals. Emotions caused by simulation of the plots of the interwoven stories from the perspectives of the main characters are thus stressed. ${ }^{55}$

$5^{\circ}$ Oatley, Best Laid Schemes, 107-108. See also K. Oatley and P.N. Johnson-Laird, "Cognitive Approaches to Emotions," Trends in Cognitive Sciences 18 (2014): 134-140; here, 134.

51 Hogan, Cognitive Science, 148-149.

$5^{2}$ E.S. Tan, Emotion and the Structure of Narrative Film: Film as an Emotion Machine (Mahwah: Lawrence Erlbaum, 1996), 98.

53 Hogan, Cognitive Science, 149-150.

54 Hogan, Affective Narratology, 43, 47-48.

55 For more substantial introductions to emotions that occur in response to an orally performed gospel, see M.R. Whitenton, "Feeling the Silence: A Moment-by-Moment Account of Emotions at the End of Mark (16:1-8)," СвQ 78 (2016): 272-289; Hartvigsen, Prepare the Way, esp. 68-82. 


\section{Conceptual Blending Theory as a Framework for Analyzing Character Constellations}

Both Schneider and Hartner point out that it is not enough to focus on individual characters. ${ }^{56}$ Hartner has developed a model where he utilizes conceptual blending theory ${ }^{57}$ to explore "the many ways our mental models of characters and their perspectives cognitively interact during the processing of a narrative text." 58

Blending theory focuses on conceptual integration networks that consist of mental spaces. Mental spaces are defined as "small conceptual packets constructed as we think and talk, for purposes of local understanding and action. Mental spaces are very partial assemblies containing elements, and structured by frames and cognitive models." ${ }^{59}$ Conceptual integration networks may consist of many mental spaces, but the minimal conceptual integration network is comprised of two input spaces, one generic space, and one blended space. Counterparts in the input spaces are connected by means of cross-space mappings, which in turn give rise to the generic space that contains what the input spaces have in common. Selected elements and frames from the input spaces are projected to the blended space, but the blend also contains an emergent structure which is not available in the input spaces ${ }^{60}$ This is the result of composition, where elements from the different input spaces are combined, completion, where background knowledge is recruited, ${ }^{61}$ and elaboration, where the blend is run as a simulation based on the principles established for the blend. ${ }^{62}$

Basic conceptual integration networks consisting of two input spaces, a generic space, and the blended space are suited to analyze the interrelationship between two characters, but a conceptual integration network is not

$5^{6}$ Schneider, "Literary Character," 628; idem, "Character Reception," 128-129; Hartner, "Constructing."

57 G. Fauconnier and M. Turner, The Way We Think: Conceptual Blending and the Mind's Hidden Complexities (New York: Basic Books, 2002); G. Fauconnier and M. Turner, "Mental Spaces: Conceptual Integration Networks," in D. Geeraerts (ed.), Cognitive Linguistics: Basic Readings (Cognitive Linguistic Research, Berlin: Mouton De Gruyter, 2006), 303-371.

58 Hartner, "Constructing," 88. Hartner also notes that previous models of character constellations focus on the structuralist binary of similarity versus difference (p. 87).

59 Fauconnier and Turner, "Mental Spaces," 307.

6o Fauconnier and Turner, "Mental Spaces," 307-312.

61 Blending theory incorporates insights from theories of gap-filling (Hartner, "Constructing" 100), as represented by Iser (Implied Reader).

62 Fauconnier and Turner, Way We Think, 48-49. The three processes explain why readers and listeners construct different blended spaces based on the same input spaces, which in turn explains different interpretations and different impressions of the characters. 
limited to two input spaces. Regarding texts with more characters, more input spaces could be added to the conceptual integration network and each input space would represent one character and her or his perspective. ${ }^{63}$ In this network, identical or comparable information in the input spaces, such as shared locations, events, or traits, could be mapped (cross-space mapping). This, in turn, gives rise to the generic space (or multiple generic spaces), because such spaces are constituted by information that is so abstract that it is common to two or more input spaces. ${ }^{64}$ Despite these similarities, the input spaces continue to exist as separate mental spaces, which underscores the existing differences between the mental character models and perspectives that constitute each input space. ${ }^{65}$ When selected elements from the input spaces are projected to the blended space to create new structures through composition, completion, and elaboration, the complexities of the characters and their perspectives may result in the creation of one or several blended spaces. Because the blend is connected to the input spaces, elements of the blend can be projected back to the input spaces. ${ }^{66}$

As I will show in the second part of the analysis of Luke 1-2, the main characters experience divine intervention in different ways. Dissimilar characters (input spaces), each representing a distinctive perspective as well as distinctive traits and roles, are portrayed in related situations (generic space) where they experience divine intervention that elicits their response. Their perspectives on and responses to God's initiative (input spaces) contain some consonances (generic space) but also some dissonances. Selected elements from the various input spaces are projected to the blended space for further exploration. In the blended space, the different perspectives on God and his initiatives become connected (composition), which generates exploration of perceptions of God and his interventions through completion (for instance, through activation of Jewish cultural memory) and elaboration. Even though God is not presented as a "physical" character in the Lukan world, the other characters' actions and

63 Hartner, "Constructing," 96-97.

64 Hartner, "Constructing," 97.

65 Blending theory incorporates the structuralist dichotomy of similarity (cross-space mappings, generic space) and difference (separate input spaces). However, the blended space is a new concept. The approach suggests that construction of meaning is not simply linear. Furthermore, the blended space is not constituted by all elements from all input spaces, because many of these elements are irrelevant to the meaning construction that takes place in the blended space. Only selected elements are projected to the blend, which leads to the emergence of new structures (Hartner, "Constructing," 98).

Hartner, “Constructing," 98-101. 
verbal responses (input spaces) to what they perceive as God's initiative constitute textual cues that readers and audience members employ to construct a complex mental character model of God, his intentions, and his initiatives.

\section{Construction of the Mental Character Models of Zechariah, Elizabeth, Gabriel, John, and God Based on Luke 1:5-25}

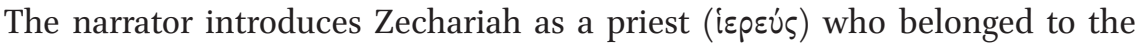
priestly division of Abijah ${ }^{67}$ and his wife Elisabeth as one of the daughters of

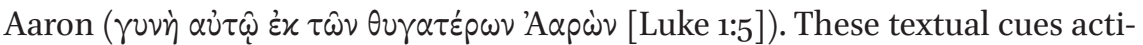
vate schemata that store knowledge about social roles, that is, the inherited role of priesthood ${ }^{68}$ and the relational roles of husband and wife. If the longterm memory of audience members contains knowledge about Aaron and his descendants, the information that Elizabeth is one of his daughters invites the inference that she also has priestly ties. The emphasis put on social roles indicates that audience members employ a top-down approach to the construction of the character models of Zechariah and Elizabeth (initial categorization).

In Luke 1:6, Zechariah and Elizabeth are both directly defined by the nar-

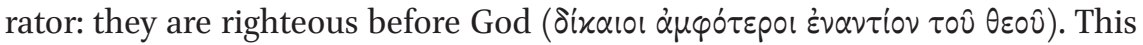
trait activates schemata that store information about righteous behavior (personal category, initial categorization). This trait is immediately elucidated by information about the couple's habitual actions, that is, they live blamelessly ( $\left.\alpha^{\prime} \mu \varepsilon \mu \pi \tau \circ \varsigma\right)$ according to the commandments and the regulations of the Lord (confirmatory categorization). ${ }^{69}$ This additional information also guides audience members whose schemata on righteousness and blameless behavior for various reasons are constituted by slightly different knowledge clusters and experiences than those mentioned here. The way these characters are characterized in Luke 1:5-6 evokes the presence of another character, namely God. Audience members may start their construction of mental character models

67 According to Autero ("Social Status," 44), this textual clue indicates that Zechariah is depicted as a non-elite priest in Luke's gospel. "Despite Zechariah's poverty and low standing within the Judean priesthood as well as within the overall social stratification analysis, we would still ascribe high status and honor to Zechariah, especially in terms of religious purity, his advanced age, and status within the small community." On Zechariah as an ordinary priest, see F. Bovon, A Commentary on the Gospel of Luke 1:1-9:50 (trans. C.M. Thomas; 3 vols.; Minneapolis: Fortress Press, 2002 [German original, 1989]), 33; and Levine and Witherington, Luke, 26.

68 On priesthood as an inherited role in Judaism, see Levine and Witherington, Luke, 26.

69 They thus keep the Torah (Levine and Witherington, Luke, 26-27). 
of God at this point, even though he is not "physically" present in the narrative world.

Audience members then learn that Zechariah and Elizabeth have no child (Luke 1:7) because she is barren $(\sigma \tau \varepsilon i \hat{\rho} \alpha)$ and they are both old ( $\dot{\alpha} \mu \varphi$ ó $\varepsilon \varepsilon p o r$

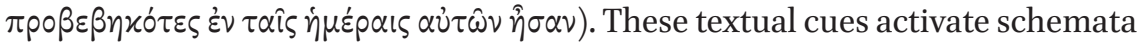
containing knowledge about gender roles, old people, and the relational roles of husband and wife (group-membership categories and social-role categories, initial categorization). These schemata may store information from Genesis, Leviticus, and Deuteronomy. According to Gen. 1:28; 9:7, and Lev. 26:9, humans were supposed to procreate, and children were regarded as one of God's blessings (Deut. 28:8-11). Moreover, God had promised that worship of him and adherence to the law would safeguard men and women from being barren (Exod. 23:25-26; Deut. 7:12-14). If this information is activated, audience members will perceive a clash between the expectations activated by the character trait "righteous" in Luke 1:6 and the associations activated by the social-role category of "barren" in Luke 1:7. ${ }^{70}$ The lack of children makes audience members infer that the married couple conforms neither to their social roles as husband and wife nor to male and female gender roles. ${ }^{71}$ Moreover, their old age invites the inference that they will not have children in the future. ${ }^{72}$ Luke 1:6-7 constitutes a conundrum ${ }^{73}$ that will focus the efforts of audience members during the subsequent performance. They may expect an explanation of the situation of these characters or a solution to the problem. If they are familiar with narratives of barren women who become pregnant due to divine intervention, such as Gen. 11:30; 17:15-18:15; 21:1-7; 25:21-26; 29:31; 30:1-24; Judges 13, and 1 Sam. 1-2:10, these textual cues will activate literary schemata, which make audience members expect, and probably prefer, a comparable solution in Elizabeth's case. ${ }^{74}$

70 See also Cocksworth, "Zechariah and Gabriel," 44; J. Feník, "Children as Gift in the Gospel of Luke," Neotestamentica 53 (2019): 79-10o (81). According to Levine and Witherington (Luke, 27), Elizabeth's infertility should not be regarded as punishment. See also Autero, "Social Status," 43 .

71 Later this inference is probably confirmed by Elizabeth's utterance in Luke 1:25b.

72 Later this inference is confirmed by Zechariah (Luke 1:18).

73 For related insights, see Carroll, Luke, 26; Cocksworth, "Zechariah and Gabriel," 45.

74 See also R.C. Tannehill, The Narrative Unity of Luke-Acts: A Literary Interpretation: Volume 1: The Gospel According to Luke (Philadelphia: Fortress Press, 1986), 15, 18; Carroll, Luke; 26. According to Levine and Witherington (Luke, 27), "John the Baptist will take his place as the last canonical figure to be born from parents presumed to be infertile." On the idea that the proclamation of such births expressed the initiative of God for the good of the whole nation, see Bovon, Luke, 34 . 
The information that Zechariah was serving as a priest before God (Luke 1:8) may continue to activate knowledge stored in schemata on priesthood and information about Zechariah's subsequent actions elaborates on the characteristics of this role (confirmatory categorization), that is, he is chosen by lot to enter the temple and offer incense (Luke 1:9). ${ }^{75}$ This information will enlighten audience members whose long-term memory does not contain information about this type of priesthood.

In the temple, the narrator introduces a new character (Luke 1:11), a heavenly

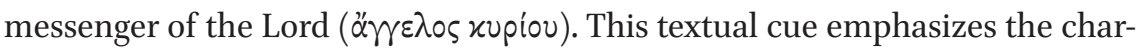
acter's group membership, his relationship with the Lord, and his functional group role. The angel's association with God indicates that audience members will regard him as a trustworthy character. His divine identity as God's messenger is confirmed by his appearance on the right side of the altar of incense in the temple. The angel's appearance is not described, but audience members may infer this information if the textual cues activate knowledge about angelic appearances in traditions stored in their long-term memory (see, for instance,

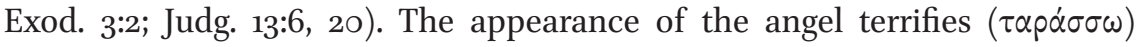
Zechariah and fear ( $\varphi \dot{o} \beta 0 \varsigma$ ) falls upon him (Luke 1:12). In Luke 1:13a, Zechariah's fearful response is initially confirmed by the angel ( $\varphi$ óßos). Audience members who have inferred that the angel's appearance was associated with fire, as was often the case, may regard Zechariah's fear as a result of the specific context. Audience members who are familiar with other traditions about divine intervention will interpret Zechariah's behavior against the backdrop of genre schemata (i.e., as a common response to divine intervention in this type of literature). ${ }^{76}$ In both cases, they will not necessarily add the trait "fearfulness" to their mental character models of Zechariah. If audience members simulate the event from the perspective of Zechariah, they will vicariously experience the proper response to divine intervention through an angelic messenger. ${ }^{77}$

The angel's utterance in Luke 1:13 indicates that Zechariah has prayed for a child (confirmatory categorization of childless) and that his prayer has been heard. ${ }^{78}$ The angel does not mention the identity of the character who heard

75 See also Bovon, Luke, 34; Levine and Witherington, Luke, 27-28.

76 On fear as the proper response to the appearance of an angel, see also Carroll, $L u k e, 28$; Levine and Witherington, Luke, 29. According to Carroll (Luke, 28-29, at 29), "fear is part of a larger narrative pattern" in Luke 1-2. "Three times human beings experience an angelic visitation, the purpose each time being an announcement of the birth, identity, and role of a child to be born, whether John or Jesus (1:11-20; 1:26-38; 2:8-14)."

77 On simulation, vicarious experience, and affective involvement, see Hartvigsen, Prepare the Way, 83-84.

78 See also Carroll, Luke, 29. Levine and Witherington (Luke, 29) argue that his prayer may go beyond children. 
the prayer, but the angel's association with the Lord suggests that it was God. ${ }^{79}$ Audience members may infer that Zechariah prayed during his service in the temple or earlier. When the angel informs Zechariah that his wife Elizabeth will bear him a son whom he will call John, ${ }^{80}$ a new character is evoked. John does not yet exist "physically" in the narrative world, but audience members will start their creation of mental character models based on the information provided by the angel. If they know the meaning of the name John, that is, "YHWH is merciful,"81 this utterance also suggests a main trait of God. ${ }^{82}$

Based on the prophetic speech of the angel, audience members will likely assume that Elizabeth and Zechariah will become parents in the future, despite their old age (potential recategorization). ${ }^{83}$ This assumption is confirmed by the angel's utterance in Luke 1:14, which focuses on the positive emotions that

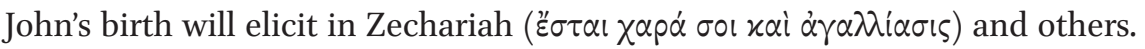
The information that many will rejoice at his birth indicates that the joy is not private but reflects the role of John in the restoration of Israel..$^{84}$ Based on simulation of the plot from Zechariah's (and Elizabeth's) perspective and goal, audience members may experience similar positive emotions because they realize that the couple will finally become parents and thus reach their goal.

Audience members recognize that the angel's portrayal of John contains a

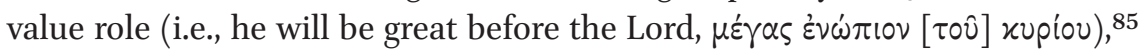
and a summary of his future actions - he will not drink wine or strong drink. ${ }^{86}$ Furthermore, they learn that John will be filled with the Holy Spirit ( $\pi v \varepsilon \dot{\mu} \mu \alpha \tau o \varsigma$ ariov), even from his mother's womb (Luke 1:15). He will turn many of Israel's sons to God (Luke 1:16) and he will precede the Lord in the spirit and power of

79 On the idea that the prayer is heard by God (implicitly), see Carroll, Luke, 29.

80 On "the proclamation of an extraordinary birth to a childless couple" as a common Jewish topos, see Bovon, Luke, 34-35.

81 Bovon, Luke, 35; H. Klein, Das Lukasevangelium (Kritisch-exegetischer Kommentar über das Neue Testament 1/3; Göttingen: Vandenhoeck \& Ruprecht, 2006), 88.

82 According to Carroll (Luke, 3o), the hymns of Mary and Zechariah will elucidate the implications of this name.

83 Carroll, Luke, 3o. According to Cocksworth ("Zechariah and Gabriel," 46), "[t]he announcement concerning John's birth resolves the problem of Zechariah and Elizabeth's childlessness as set up in the exposition." However, this problem is not resolved until the child is born.

84 See also Cocksworth, "Zechariah and Gabriel," 47; Levine and Witherington, Luke, 29. According to Bovon (Luke, 35), "[h] appiness and rejoicing are not secular, but feelings of the believers while in God's presence."

85 Bovon (Luke, 36) claims this designation means that John will become a prophet.

86 According to Bovon (Luke, 36 ), this information is reminiscent of priestly regulations. John is thus also placed within a priestly framework. According to Levine and Witherington (Luke, 3o), it also places John within the Nazirite tradition. 
Elijah and prepare the people for him (Luke 1:17). ${ }^{87}$ To audience members who are familiar with the traditions about Elijah, the comparison of John to Elijah suggests that John will embody the functional group role of a prophet in the gospel, ${ }^{88}$ which may activate genre schemata associated with this role.

Audience members will most likely interpret Zechariah's response to the angel (Luke 1:18a) as a request for a sign ${ }^{89}$ that will corroborate the content of the angel's prophetic words. In that case, they will infer that his request reflects the couple's age (Luke 1:7), an inference that is immediately confirmed in Luke 1:18b. In Luke 1:19, the angel presents his proper name, Gabriel, and his roles with regard to God: he stands in God's presence and has been sent by God to announce the good news (personal category and functional group role, confirmatory categorization ${ }^{90}$ ). This information substantiates Gabriel's authority ${ }^{91}$ and his subsequent ability to make Zechariah temporarily silent and unable to speak (Luke 1:20). If audience members are familiar with traditions about Abraham, they will probably recognize some similarities between Zechariah and Abraham (Gen. 17:15-22). However, in contrast to Abraham, who questions God, ${ }^{92}$ Zechariah demands a sign (Luke 1:18a), which is interpreted by the angel as unbelief (Luke 1:20), ${ }^{93}$ and Zechariah is punished. ${ }^{94}$ To audience members who are familiar with Gen. 17:15-22, this turn of events is unexpected. ${ }^{95}$ Luke 1:22 confirms that Zechariah has in fact become mute and possibly deaf ( $\varkappa \omega \varphi o ́ \varsigma) .{ }^{96}$ This information reinforces the authority of Gabriel

87 On the idea that John's role is to prepare the people for the Lord, see also Carroll, Luke, 3031; Cocksworth, "Zechariah and Gabriel," 47-48. On John as the precursor of Jesus, see L.T. Johnson, The Gospel of Luke (Sacra Pagina Series, 3; Collegeville: The Liturgical Press, 1991), 33. On John as the precursor of God, see Bovon, Luke, 37. At this stage, audience members who hear the gospel for the first time will probably think John is the precursor of God. Later, they will realize that John is the precursor of Jesus.

88 See also Carroll, Luke, 30-32; Bovon, Luke, 36-37.

89 According to Bovon (Luke, 38), such signs are often given by angels in the Hebrew Bible, but a demand for a sign can be regarded as an indication of weak faith.

9o See Luke 1:11.

91 According to Bovon (Luke, 38), the angel becomes offended, and he finds Zechariah's unbelief unbelievable.

92 According to Carroll (Luke, 33), Zechariah's question recalls the question formulated by Abraham.

93 On Zechariah's question as an indication of lack of insight and trust, see Carroll, Luke, 33.

94 See also P. Borgman, The Way According to Luke: Hearing the Whole Story of Luke-Acts (Grand Rapids and Cambridge: Eerdmans, 2006), 19.

95 Abraham does not ask for a sign, but he questions God (Genesis 17:17). Levine and Witherington (Luke, 30-31) argue that questioning a divine revelation is common.

96 Bovon (Luke, 38) argues that Zechariah's muteness "is both a punishment and a sign that reverses Zechariah's unbelief." On this as a punitive miracle, see Cocksworth, "Zechariah and Gabriel," 46. 
and possibly Zechariah's unbelief. ${ }^{97}$ If audience members simulate the developments of the plot based on their own preferred ending of the narrative about the couple, Zechariah's response to the event, which indicates doubt about the veracity of the angel's utterance, may elicit emotions of surprise.

After Zechariah returns to his home, Elizabeth becomes pregnant (Luke 1:23-24). Audience members will most likely infer that they conceive naturally, because the gospel does not contain textual cues that contradict conventional schematic knowledge about marital relations. ${ }^{98}$ Despite this fact, the change of social-role categories from "barren" to "pregnant" at Elizabeth's age (recategorization) requires an explanation. From the point of view of Elizabeth, the explanation is supernatural: the Lord has done this for her (Luke 1:25) ${ }^{99}$ Moreover, she claims that the Lord has removed her disgrace. ${ }^{100}$ The latter utterance will probably activate Gen. 30:22-23. ${ }^{101}$ Because Zechariah has become temporarily mute, audience members must infer how Elizabeth knows about God's initiative. Elizabeth's successful pregnancy is supported by information about the progress of her pregnancy in Luke 1:24 and Luke 1:26 (confirmatory categorization). Elizabeth's emotional reaction to this event is not portrayed; she could be happy, however, the fact that she hides for five months could suggest that she experiences a more negative emotion: she could be afraid to miscarry. If audience members continue to simulate the developments of the plot based on the overall goal of Elizabeth and Zechariah, positive emotions will be elicited, such as joy or happiness, because the birth is approaching.

The utterances of the narrator and the actions and utterances of Zechariah, Elizabeth, and Gabriel suggest that audience members should infer the presence of another character in Luke 1:5-25: God. This character has a temple where priests present offerings and he sends Gabriel as a messenger to Zechariah. ${ }^{102}$ Audience members may infer that he answers prayers, which in this case results in Elizabeth's pregnancy. Elizabeth's perspective on her pregnancy (Luke 1:25) suggests to audience members that God is her savior

$97 \quad$ See also Carroll, Luke, 34 .

98 For similar insights, see Bovon, Luke, 40; Carroll, Luke, 36.

99 On God's agency, see also Feník, "Children," 82-83.

100 Bovon (Luke, 40) argues that childlessness was regarded as the fault of the woman at that time. However, Zechariah's age is also in focus, like the story of Abraham and Sarai (Genesis 17:17).

101 The activation of literary schemata storing knowledge about the matriarchs and patriarchs will draw attention to events where God has intervened on behalf of individuals and for his people previously; for instance, the events surrounding the establishment of the covenant.

On God's initiative, see also Carroll, Luke, 28. 
(functional group role), but the term is not yet explicitly mentioned. Audience members assemble these inferences to create a mental character model of God.

\section{Construction of the Mental Character Models of Gabriel, Joseph, Mary, Jesus, and God Based on Luke 1:26- 38}

When Gabriel is reintroduced by the narrator in Luke 1:26, the information that he is an angel or messenger sent by God sustains the main aspects of the previous categorization, in particular his functional group role, which facilitates confirmatory categorization. Luke 1:26 may activate the previous event in the temple where Gabriel interacted with Zechariah (Luke 1:11-20). ${ }^{103}$ If this event is activated, audience members will likely remember his authority. This time Gabriel is not sent to the temple, but to Nazareth in Galilee.

Before audience members even know her name, Mary is introduced by the narrator as a virgin ( $\pi \alpha \rho \theta \varepsilon$ है $0 \varsigma),{ }^{104}$ engaged to a man called Joseph, of the house of David. ${ }^{105}$ Thus, her social roles of virgin and engaged woman, which are intimately related to her female gender role (group-membership category), form the basis of audience members' initial categorization of Mary. Joseph is also categorized according to his social roles (i.e., his kinship with David and his engagement to Mary). This is the only information audience members learn about Joseph at this point. ${ }^{106}$ In contrast to the previous episode, the exact location of Mary is not mentioned. Audience members do not automatically infer information about the environment, but some may infer that she is in her home. ${ }^{107}$

The mental character model of Mary is expanded by the textual cues supplied by her dialogue with Gabriel and by how their speech acts are introduced by the narrator. The angel greets her and addresses her as a favored person ( $\varepsilon \chi \alpha \rho i \tau \omega \mu \varepsilon v \eta)$, which is elucidated by the following information: "The Lord is with you" (Luke 1:28). Based on this characteristic, audience members will

\footnotetext{
103 On shared elements and differences between this annunciation scene and the previous, see Johnson (Luke, 38-39, at 38). He also claims that this scene may make sense to Hellenistic readers accustomed to "birth-accounts of extraordinary people." This information may prime or activate Isa 7:14 LXx. See Bovon, Luke, 49; Carroll, Luke, 39. See also Carroll, Luke, 38. For different character reconstructions of Mary, see C. Bennema, "Character Reconstruction in the New Testament (2): The Practice," The Expository Times 127 (2016): 417-429.

106 The importance of this information is pointed out by the angel in Luke 1:32.

107 See Carroll, Luke, 38-39. Many artists also make such inferences.
} 
regard Mary as a character who has a special standing with the Lord (personal category). Mary reacts to this utterance with perplexity, or fear, ${ }^{108}$ and ponders its meaning (Luke 1:29). ${ }^{109}$ If their knowledge of encounters between humans and divine beings is activated, which is probable because of the previous event in the temple, audience members may simply regard Mary's response as an appropriate reaction to the context and not as an indication that new character traits should be introduced into their mental character models of Mary. The angel interprets her response as fear (Luke 1:30a), which substantiates the conventional character of Mary's reaction. Then the angel repeats the information about Mary's favor with God, which underscores the information already included in audience members' mental character model of Mary (confirmatory categorization).

Like the event in the temple, the angel announces a future alteration of one of Mary's main social roles (prospective recategorization). In this case, the virgin will conceive and become the mother of a son, Jesus (Luke 1:31).110 This development explains Mary's favor with God.111 The angel's prophetic speech will probably activate audience members' schematic knowledge about conventional marriage relations, which will enable them to make inferences about how Mary conceives. ${ }^{112}$ Such inferences will almost certainly include the assumption of sexual relations, like the previous episode concerning Zechariah and Elizabeth. If they are familiar with other traditions about Jesus, this may not be the case. If audience members simulate the plot from Mary's perspective based on the information that she is a virgin, the angel's utterance will elicit surprise.

Jesus' name may activate knowledge about its etymological meaning, that is, "God saves."113 If so, audience members will infer that God is a savior (functional group role, confirmatory categorization). In this episode, the angel first emphasizes Jesus' relational role as the son of Mary (initial categorization). Then Jesus is directly defined by his future status: he will be great (value role).

108 Mary's reaction could prime or activate Zechariah's reaction. See also Carroll, Luke, 39. According to Carroll, the compound verb $\delta \varepsilon \tau \tau \alpha \rho \alpha \chi \chi \emptyset \eta$ could be translated "she was troubled." Levine and Witherington (Luke, 34) suggest terrified. These translations are in line with the angel's response. Bennema ("Practice," 424) points out that aspects of Mary's inner life are in focus.

109 This is a theme in Luke. Borgman, Way, 23-24.

$110 \quad$ For related insights, see Bennema, "Practice," 424.

111 For related insights, see Carroll, Luke, 40. According to Levine and Witherington (Luke, 34-35), the reason for Mary's favor is not mentioned.

112 For related insights, see Levine and Witherington, Luke, 35.

113 Klein, Das Lukasevangelium, 97. 
Jesus' status anticipates the subsequent social-role and functional group role

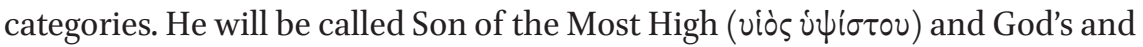
Jesus' future actions indicate that Jesus will be given the throne of his ancestor David and be king of Jacob's house for eternity (Luke 1:32-33). ${ }^{114}$ Depending on the previous traditions stored in the long-term memory of audience members, Luke 1:32-33 may prime or activate interrelated schemata for social and functional group roles, such as son or king, possibly a Davidic Messiah-king (2 Sam 7:12-16). ${ }^{115}$ However, as the story develops, their schemata will probably be adjusted or even supplied by a specific schema, or a subdivision of a schema, which stores information about Jesus as king and Son of God (individuation).

In contrast to the previous inferences based on the conventional schema for marriage relations, Mary's question in Luke 1:34 suggests that she has not had

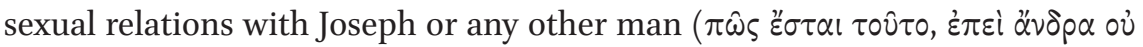
$\gamma(v \omega \dot{\omega} \sigma \omega ;)$. Unlike Zechariah, Mary does not ask for a sign, she rather asks about practicalities. ${ }^{116}$ Her question confirms the initial categorization of Mary as a virgin ${ }^{117}$ and for audience members who simulate the plot from Mary's perspective, the emotion of surprise may persist. The angel's response (Luke 1:35) substantiates Mary's special relationship with the Lord (confirmatory categorization) and suggests that the pregnancy and Jesus are of divine origin $(\pi \nu \varepsilon \hat{u} \mu \alpha$

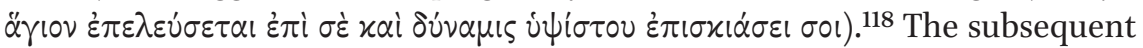
utterance contains a direct definition of Jesus, that is, he is holy $(\ddot{\alpha} \gamma 10 \varsigma)^{119}$ and will be called the Son of God (viòs $\theta \varepsilon \circ \hat{)}$ ). This information may activate the relational role schemata of father and son. Inferences based on this information may replace the previous inferences of some audience members that Joseph is Jesus' father (recategorization). Furthermore, Jesus' divine descent will qualify his role as a Davidic Messiah-king.

Because Elizabeth and her relation to Mary is mentioned, the information in Luke 1:36 will most likely activate the previous events in the Lukan world.120 This information substantiates the previous recategorization of Elizabeth as

114 On Jesus' double paternity (Joseph of the house of David and God), see Levine and Witherington, Luke, $35^{-36}$.

115 See also Tannehill, Luke-Acts, 25-26; Carroll, Luke, 40-41. Later, Luke 1:35 suggests that "Son of God" does not merely refer to his role as a king, but to God's role in Mary's pregnancy.

116 Levine and Witherington (Luke, 36) argue that Mary wants to know practicalities, not possibilities (like Zachariah). On related insights, see Johnson, Luke, 39; Borgman, Way, 22.

117 See also Carroll, Luke, 42.

118 On God's sovereign initiative regarding Jesus' birth, see Carroll, Luke, 39.

119 This may reflect the spirit's role in Jesus' birth, see Carroll, Luke, 42.

120 According to Levine and Witherington (Luke, 34, 36-37), the fact that Mary and Elizabeth are related indicates that Mary has priestly connections, but we do not know anything about her class, family, or appearance. According to Johnson (Luke, 31), Mary has "no 
a pregnant woman, but also the initial categorization of her as "barren" (confirmatory categorization). The angel's utterances draw attention to the surprising turn of events for the two women and underscore the role of God in

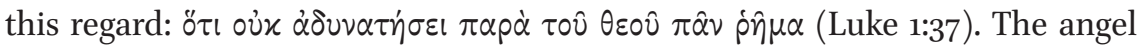
emphasizes a main trait of God (i.e., his omnipotence), which is confirmed by Elizabeth's unexpected pregnancy. ${ }^{121}$ The angel's divine status adds credibility to his utterance. Luke 1:36-37 also underscores the likelihood that the angel's prophetic utterances will be fulfilled.

Mary responds by designating herself as a servant or slave ( $\left.\delta \circ v^{\prime} \lambda \eta\right)$ of the Lord (functional group role) who accepts her fate according to the prophecy. Audience members may interpret her self-designation as a reflection of her humble station. However, if audience members are familiar with traditions about other servants or slaves of the Lord, such as Joshua (Judg. 2:8), Paul (Tit 1:1), James (Jas 1:1), and the prophets (Amos 3:7), they may interpret her role against the backdrop of a more varied schema, ${ }^{122}$ possibly by creating a new subcategory within this existing schema.

\section{Construction of the Mental Character Models of Mary, Elizabeth, John, and God Based on Luke 1:39-56}

Mary's journey to visit Elizabeth (Luke 1:39-40) is an action that different audience members will regard as an indication of different traits, preferences, or goals (personal categories). It can suggest belief in the previous utterance of the angel, that she is curious, that she doubts the angel, or that she wants to see Elizabeth's pregnancy (Luke 1:36) with her own eyes. ${ }^{123}$

When Mary enters Elizabeth's home and greets her, John recognizes the importance of Mary (and Jesus) even as a fetus by leaping in Elizabeth's womb. The meaning of this act is not explicit, ${ }^{124}$ but it seemingly underscores

official position among the people," she is not righteous, and she is not located in a cultic setting. "She is among the most powerless people in her society:" young, female, and poor. On Elizabeth's pregnancy as a sign, see Bovon, Luke, 38; Carroll, Luke, 42-43; Levine and Witherington, Luke, 36; Feník, "Children," 82.

122 On the servants or slaves of God, see Levine and Witherington, Luke, 37.

123 According to Bennema ("Practice," 424), Mary shows initiative.

124 Later, Elizabeth interprets this act as joy (Luke 1:44), but audience members may also regard it as an early confirmation of John's future role as a prophet. On this act as a sign that John is a prophet, see Johnson, Luke, 40. See also Bovon, Luke, 58-59; G. Nassauer, "Gegenwart des Abwesenden. Eidetische Christologie in Lk 1.39-45," New Test Stud. $5^{8}$ (2011): 69-87; here, 75 . 
Elizabeth's response. She is filled with the Holy Spirit and she cries out (Luke 1:41-42). These characteristics will probably activate schemata that store knowledge about the functional group role of a prophet. ${ }^{125}$

Elizabeth's utterance confirms that Mary is singled out; in this case, she is blessed (personal category). Luke 1:42 may activate Gabriel's utterances in Luke 1:28-30, which focus on Mary's special relationship with the Lord. Through Elizabeth's speech (Luke 1:42-43), audience members are then informed that Mary is pregnant ${ }^{126}$ and that the fetus is blessed too. Luke 1:31-35 is probably activated by this information and audience members will recategorize Mary, that is, the former virgin is now pregnant and the future mother of the Lord. Moreover, by calling Mary $\dot{\eta} \pi\left\llcorner\sigma \tau \varepsilon \dot{\sigma} \sigma \alpha \sigma \alpha,{ }^{127}\right.$ in this case in the fulfillment spoken to her by the Lord (Luke 1:45) through his messenger, Elizabeth introduces a new character trait of Mary (personal category). She believes, in contrast to Zechariah (Luke 1:20).

Mary responds by praising ( $\left.\mu \varepsilon \gamma \alpha \lambda v^{\prime} \omega \omega\right)$ the Lord (Luke 1:46-55). Her praise may prime or activate 1 Sam 2:1-10. Mary once more employs a functional group role to describe her relationship with God (Luke 1:48): she is his servant or slave $\left(\delta \circ v^{\prime} \lambda \eta\right){ }^{128}$ Moreover, she will be considered blessed by future generations. Her utterances thus confirm previous categorizations. Mary's utterances in Luke 1:46-48 indicate that she experiences positive emotions, such as happiness, and audience members who simulate the plot from her perspective may experience similar emotions.

Mary's praise of the Lord characterizes him in various ways: She begins by stating he is her savior ( $\sigma \omega \tau \dot{\eta} \rho$, functional group role, Luke 1:47). ${ }^{129}$ Moreover, she mentions several characteristics and character traits (personal categories): He is the Mighty One who has done great things for her, his name is holy (Luke 1:49), and he is merciful to those who fear him ( $\varepsilon^{\prime \prime} \lambda \varepsilon \circ$, Luke 1:50). ${ }^{130}$ The acts of the Lord that are subsequently described (Luke 1:51-54) will probably confirm

125 On Elizabeth's prophetic insights, see Johnson, Luke, 41. On Elizabeth as a prophet, see also Bovon, Luke, 59. According to Nassauer (“Gegenwart des Abwesenden," 75), John's association with the Holy Spirit may occasion Elizabeth being filled with this spirit.

126 On related insights, see Levine and Witherington, Luke, 39.

127 According to Bovon (Luke, 59), Mary's belief repeats her attitude in Luke 1:38. On Mary's faith, see also Levine and Witherington, Luke, 39 .

128 This designation may prime or activate 1 Sam 1:11.

129 According to Carroll (Luke, 49), "[b]oth epithets for God, Lord and Savior, amount to a demotion of the Roman emperor."

130 According to Bovon (Luke, 61), emphasis is not on God's essence, but on the way his acts correspond to this essence and that they "presuppose a relationship between God and his people." 
audience members' previous categorization of him as mighty, a savior, ${ }^{131}$ and merciful. ${ }^{132}$ New categorizations may include God's role as a provider of food, his fair-mindedness (Luke 1:53), and his roles as a helper of his people and a communicator with them from Abraham and through the ages (Luke 1:54-55). The latter categorization is confirmed by Gabriel's functional group role as the Lord's messenger in the Gospel of Luke 1-2. In the narrative world, God's interventions have already changed the status of Elizabeth and Mary. Moreover, Mary speaks as if God has already changed (aorist) the situation of the humble, the hungry, the rich, and Israel (Luke 1:52-55). ${ }^{133}$ God's interventions have probably elicited positive emotions in the characters (as explicitly uttered by Mary in Luke 1:46-47) and in audience members who simulate the plot based on identification with the main characters. The information about God's actions may elicit similar positive emotions because they indicate a positive future ending, which may be preferred by many audience members.

\section{Construction of the Mental Character Models of Elizabeth, Zechariah, God, and John Based on Luke 1:57-80}

The event described in Luke 1:57 indicates that Elizabeth's social role has now changed from that of a pregnant woman to that of a mother (recategorization). Thus, Gabriel's prophetic speech has been fulfilled. Through Luke 1:58, the narrator points out the joy of Elizabeth, ${ }^{134}$ her neighbors, and her relatives. Simulation of this event from their perspective will probably elicit similar positive emotions in audience members.

When Elizabeth and Zechariah proceed to circumcise the child (Luke 1:59), this action confirms audience members' previous categorization: these parents are righteous (Luke 1:6). ${ }^{135}$ During this event, Elizabeth says that the child

131 Carroll (Luke, 49) claims that Luke 1:48-55 focuses on God's activity as Savior.

132 According to Levine and Witherington (Luke, 40), Mary's song is about the power of God. On emphasis on power and mercy, see Tannehill (Luke-Acts, 29).

133 According to Levine and Witherington (Luke, 42-43), Mary embodies the role of a prophet, who in her imagination believes that God has already performed these acts. According to Johnson (Luke, 43), "Mary's praise for what God had done to her personally widens out to include what God does for 'all who fear him' in every age, including what God is doing for Israel by the birth of its Messiah." For related insights, see Bovon, Luke, 62; Carroll, Luke, $47-48,5^{\circ}$.

134 On the fact that the significance of the event for the mother is described first, then the relevance for the people, see Bovon, Luke, 70 .

On their observance of the Torah, see Johnson, Luke, 45, 48; Carroll, Luke, 55 . 
shall be called John (Luke 1:6o). ${ }^{136}$ This name will activate traditions about God's mercy stored in the long-term memory of audience members who know the etymology of the name. Earlier, Gabriel disclosed this name to Zechariah, who has been mute, and possibly deaf, since his interactions with the angel. ${ }^{137}$ Audience members will either infer that Zechariah has somehow managed to communicate the name to Elizabeth, ${ }^{138}$ that she has been supernaturally informed, or they may not notice this conundrum because they have learnt about the name during the narration of the earlier events.

By means of signs, Zechariah is asked what he wants to call the child (Luke 1:62). These actions confirm to audience members that he is both mute and deaf ( $\varkappa \omega \varphi o ́ s)$. When Zechariah discloses the child's name in writing (Luke 1:63), ${ }^{139}$ he is once more able to speak, ${ }^{140}$ and immediately he praises God (Luke 1:64). ${ }^{141}$ Like his wife Elizabeth earlier (Luke 1:41), he is filled with the Holy Spirit and prophesies (Luke 1:67). ${ }^{142}$ This information may indicate to audience members that they should interpret Zechariah's acts as signs that he embodies the functional group role of a prophet, or they may rather attribute his utterance to the specific situation, where his ability to speak has just been restored in response to his confirmation of John's name. His ability to speak may also suggest that his faith has been restored (cf. Luke 1:20). This event may elicit positive emotions in audience members based on the positive development of the plot viewed from the perspectives of Elizabeth and Zechariah.

As in the previous pericopes, information about God, who is not "physically" present in the narrative world, is revealed. In Luke 1:58, the neighbors and relatives learn that Elizabeth's delivery is the result of God's mercy ( Their interpretation of the event may activate and thus confirm Mary's earlier

\footnotetext{
136 On the fact that this represents a break with tradition, see Levine and Witherington, Luke, 43-44. On the parents' choice of name as a sign of fidelity to God, see Carroll, Luke, 55 . See also Bovon, Luke, 71; Levine and Witherington, Luke, 2018, 44.

${ }_{13} 8$ See also Levine and Witherington, Luke, 43. According to Bovon (Luke, 70), Elizabeth's knowledge is a sign of her election.

139 On Zechariah's literacy, see Levine and Witherington, Luke, 44. On this as an act of trust and obedience to God, see Carroll, Luke, 55. For related insights, see Bovon, Luke, 70.

On this event as a miracle, see Levine and Witherington, Luke, 44. On God's role in opening Zechariah's mouth, see Carroll, Luke, 55 .

141 On the fact that Zechariah is starting to believe, see Bovon, Luke, 69-70.

142 See also Bovon, Luke, 71; Carroll, Luke, 58; Levine and Witherington, Luke, 44. According to Johnson (Luke, 45), this constitutes programmatic prophesy, which guides the understanding of the subsequent narrative. According to Carroll (Luke, 58), "Luke invites readers to trust Zechariah's message and so join the chorus of joyful praise."

143 Levine and Witherington $($ Luke, 43) point out that "[ $\mathrm{t}]$ he neighbors recognize the divine mercy showed to Elizabeth." See also, Carroll, Luke, 54.
} 
utterance that God is merciful to those who fear him (Luke 1:50). For some audience members the etymological meaning of the name John further highlights this character trait.

The first part of Zechariah's prophecy provides further information about God. ${ }^{144}$ It starts with a blessing that focuses on God's acts. Audience members will probably interpret God's actions based on schemata storing the relational roles of God and his people and literary traditions about their interactions. Based on God's actions, they may infer that he is a redeemer ( $\lambda v \tau \rho \omega \tau \eta \dot{s} s)$ of the

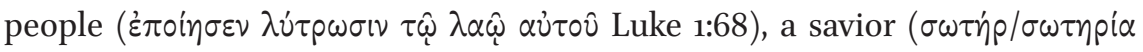

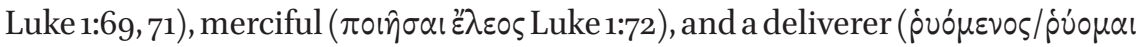
Luke 1:74). Moreover, they are reminded that he is an initiator and keeper of the covenant to Abraham (Luke 1:72-73). ${ }^{145}$ Many of these characteristics overlap, and they focus on different aspects of how God protects his people. This information will probably prime or activate related traditions stored in the long-term memory of audience members. Moreover, it confirms audience members' previous categorizations, such as those based on Luke 1:47 (God is a savior) and Luke 1:13, 50, $5^{8}$ (God is merciful). ${ }^{146}$

The second part focuses on John's future functional group role as a prophet

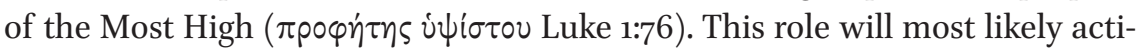
vate related schemata storing the traditions about the prophets, and activation of Luke 1:7o may suggest that God will speak through John. Zechariah interprets John's role as going before the Lord to prepare his way and giving knowledge of salvation (Luke 1:76-77). ${ }^{147}$ Audience members may regard John's actions as a further confirmation that God is merciful (Luke 1:76-78). ${ }^{148}$ The narrator then summarizes John's childhood (Luke 1:80): he grew, became strong in spirit, and was located in the wilderness before he appeared publicly. The textual cue spirit $(\pi v \varepsilon \hat{\mu} \mu \alpha)$ will most likely activate Luke 1:15. In that case, audience members may infer that his association with the Holy Spirit has grown with age. This cue may also confirm John's role as a prophet because earlier in the gospel prophets and prophetic speech are associated with the Holy Spirit (Luke 1:17, $41,67)$.

\footnotetext{
144 Whereas Mary begins with her own experience and then moves to God's role in history, Zechariah starts with the visitation and then John's role. Johnson, Luke, 48.

145 On the fundamental role of this covenant, see Johnson, Luke, 46. On this covenant, see also Carroll, Luke, 59; Levine and Witherington, Luke, 45 .

146 On God's mercy, see also Carroll, Luke, 59-6o; Tannehill, Luke-Acts, 29.

147 According to Carroll (Luke, 6o-61), it is ambiguous whether John will go before God, the Father, or Jesus. According to Levine and Witherington (Luke, 46), the "Lord" refers to Jesus.

148 According to Carroll (Luke, 61), God's mercy comes from his innermost being.
} 


\section{Construction of the Mental Character Models of Joseph, Mary, Jesus, the Shepherds, and the Angels Based on Luke 2:1-21}

Whereas Gabriel previously visited Mary in Nazareth in Galilee, audience members now learn that Joseph and Mary went from this town to Bethlehem. The information presented in Luke 2:4-5 confirms audience members' previous categorizations of Joseph: he is of Davidic descent (kinship role) $)^{149}$ and an engaged man. The information in Luke 2:5 confirms Mary's social roles as an engaged, pregnant woman.

While they are in Bethlehem, Mary gives birth to her firstborn ( $\pi \rho \omega \tau$ tó 0 x०५) son, ${ }^{150}$ wraps him in strips of cloth, and lays him in a manger ${ }^{151}$ (Luke 2:6-7). This event will probably activate Gabriel's prophecy about the birth of Jesus (Luke 1:30-33). Audience members' realization that the prophecy is fulfilled confirms the angel's status as a reliable character. The birth changes Mary's social role from that of a pregnant woman to that of a mother (recategorization), and the nursing of her son underscores their relational roles. If audience members simulate the events from the perspective of Mary, this event may continue to elicit positive emotions, such as joy. The description of the baby's clothing is a new feature in Luke. This accentuation of aspects of a character's physical appearance draws the attention of audience members to Jesus.

In Luke 2:8, the scene shifts to a group of shepherds who keep watch over their flock. ${ }^{152}$ These textual cues may activate schemata storing knowledge about the social role of "shepherd" ( $\pi$ or $\mu$ 'v, occupational role), and the characters' actions correspond to those expected of this role. The shepherds are vis-

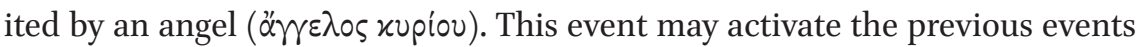
where Gabriel visited Zechariah (Luke 1:11-20) and Mary (Luke 1:26-38). The narrator does not reveal the name of the angel, ${ }^{153}$ but if these two events

149 On the fact that Jesus thus is established as "the heir to David's throne" and his birth in Bethlehem, see Levine and Witherington (Luke, $5^{6-57)}$. See also Carroll (Luke, 66).

150 This description of Jesus confirms that Mary is a virgin (Levine and Witherington, Luke, 57). On the idea that the term places Jesus in a special relationship with God, see Bovon (Luke, 85-86).

151 On the symbolism of this location, see Levine and Witherington, Luke, 58; Carroll, Luke, 67 .

152 According to Bovon (Luke, 87); Levine and Witherington (Luke, 58), this scene may prime or activate various Greek and Roman nativity accounts (Oedipus, Paris, and Romulus) and cultural memory associated with shepherds (Rachel, Moses, and David). The shepherds represent ordinary people (Bovon, Luke, 86-87; Levine and Witherington, Luke, 58-59). According to Johnson $\left(\right.$ Luke, $\left.5^{2}\right)$, they are "among the lowest-esteemed laborers." 
are activated, audience members may infer that the angel is Gabriel. ${ }^{154}$ The appearance of Gabriel was not described in the previous events, but audience members may have inferred it based on schemata stored in their long-term memory. In Luke 2:9, however, the angel seemingly reflects the shining glory

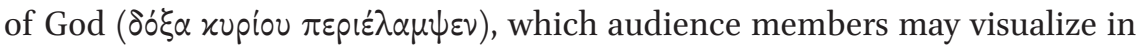
different manners. Like other characters who have encountered divine beings, the shepherds become fearful ( $\varphi$ ó ence members could also in this case infer that this reaction should not be considered as a character trait, but rather as the conventional response to divine intervention.

The angel's task is to proclaim good news of great joy to all people (Luke 2:10). His proclamation conforms to the schematic expectations associated with his role as God's messenger. ${ }^{155}$ The angel proclaims the birth of a savior

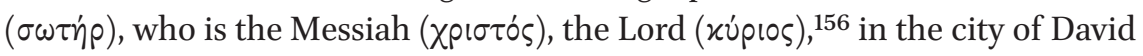
(Luke 2:11). ${ }^{157}$ The role of "savior" could activate the utterance of Mary, who calls God "savior" (Luke 1:47). ${ }^{158}$ Moreover, it could prime or activate associated ideas where this specific role is not explicitly mentioned, such as elements of Zechariah's prophetic speech and blessing (Luke 1:68-69, 71, 73-74). Thus, this functional group role may confirm to audience members that the connections between God and Jesus go beyond their familial ties. The functional group

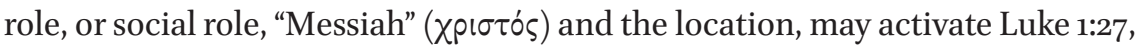
$3^{2-} 33$, where Jesus' ancestry, name, and future roles are presented. In that case, audience members will recall the characteristics of this role.

The angel offers the shepherds a sign: an infant wrapped in cloths lying in a manger (Luke 2:12). ${ }^{159}$ This utterance probably activates the physical description of the child in Luke 2:7. If the earlier interactions between Zechariah and the angel are activated, audience members will remember that Zechariah asked for a sign (Luke 1:18). Whereas Zechariah was punished for his request,

154 See also J.B. Green, The Gospel of Luke (Grand Rapids and Cambridge: Eerdmans, 1997), 131; Bovon, Luke, 87 .

155 The fact that the angel proclaims good news may activate Luke 1:19.

156 On these terms, see Bovon, Luke, 89.

157 According to Levine and Witherington (Luke, 6o), the angel's utterance may activate Isa 9:6. On the good news as the birth, see Bovon, Luke, 88.

158 On this information as the soteriological and Christological significance of the good news and birth, see Bovon, Luke, 88. On the fact that this epithet is also used of God, see Johnson, Luke, 43-44. It is also used of major figures in the Hellenistic world, such as heroes, healers, and the emperor (Levine and Witherington, Luke, 6o). See also Bovon, Luke, 88-89.

See also Levine and Witherington, Luke, 61. 
the angel offers the shepherds a sign unsolicited. ${ }^{160}$ Moreover, the angel is joined by a multitude of angels who praise God (Luke 2:13-14). In contrast to the earlier divine interventions, this time heavenly beings, not humans, bless God. If audience members recognize these variations over a similar script, they will realize that the presence of the multitude of angels singles out this event as the most important of the divine interventions in the nativity stories. The good news proclaimed by the angel (Luke 2:10) and the angels' response (Luke 2:14) will probably elicit positive emotions of joy, because they indicate a positive future ending, which may be preferred by many audience members.

When the angels have returned to heaven (Luke 2:15), the narrator states that the shepherds decide, like Mary (Luke 1:39-56), to see the thing that has taken place, which the Lord revealed to them (through his messenger). ${ }^{161}$ Audience members may infer that this action indicates character traits, such as their belief (in the message of the angel) or their curiosity. The narrator's account of the shepherds' observations and utterances in Luke 2:16-17 may activate the information presented in Luke 2:7 and Luke 2:12, despite the lack of detail. ${ }^{162}$ If these events are activated, audience members may infer these details based on the previous events. The shepherds' observations confirm to audience members that the angel is trustworthy. The information that the shepherds report the words of the angel may also activate his message (Luke 2:11-12). Even though the $\pi \dot{\alpha} \nu \tau \varepsilon \varsigma$ of $\alpha$ xov́ $\sigma \alpha \nu \tau \varepsilon \varsigma$ in Luke 2:18 have not seen the angels themselves, they react according to a script appropriate for divine intervention, this time not with fear, but amazement $(\theta \alpha u \mu \alpha \dot{\zeta} \zeta \omega)$. In contrast, Mary treasures and ponders $(\sigma \nu \mu \beta \alpha \lambda \lambda \omega)$ the words in her heart. ${ }^{163}$ Because Mary's action is singled out, it may indicate to audience members that her actions reflect a character trait; in this case, she could be categorized as contemplative (personal category).

The shepherds did not immediately provide a verbal response to the angelic visit, but rather a physical action (Luke 2:15-16). When the sign is confirmed, however, they praise God (Luke 2:20) ${ }^{164}$ like Zechariah after the circumcision of John and like Mary during her initial meeting with Elizabeth. In the nativity stories, praise of God is thus the appropriate response to the signs of his interventions, as demonstrated by human and divine characters.

\footnotetext{
16o See also Bovon, Luke, 89; Carroll, Luke, 79 .

161 On the idea that the angels speak for God, see Levine and Witherington, Luke, 62.

162 On this event as prophecy fulfillment, see Johnson, Luke, 52.

163 On Mary "as a model of the believer," see Bovon, Luke, 93.

164 On the shepherd's response as a model response, see Carroll, Luke, 72.
} 
Like John, Jesus is circumcised and named on the eighth day. ${ }^{165}$ Jesus' name may activate knowledge of its etymological meaning, that is, God saves. Through Luke 2:21, the narrator explicitly reminds audience members about Gabriel's prophecy to Mary before she became pregnant (Luke 1:31-33). Other events in the Gospel of Luke 2 may already have activated the previous events, but this utterance makes the connections obvious to audience members who have not noticed these connections.

\section{Construction of the Mental Character Models of Mary, Joseph, Jesus, Simeon, and Anna Based on Luke 2:22-39}

Based on Luke 2:22-24, audience members learn that Joseph and Mary want to adhere to the Torah with its commandments and regulations. ${ }^{166}$ Moreover, by naming their child Jesus, his parents demonstrate obedience to the angel (Luke 1:31). ${ }^{167}$ Based on Mary and Joseph's obedience to the Torah, audience members will categorize them as righteous people (personal category) like Elizabeth and Zechariah (Luke 1:6), and their modest sacrifice (Luke 2:24) indicates that they should be categorized as poor (group-membership category). ${ }^{168}$ If Luke 2:23 activates the information that Mary is a virgin and that Jesus is her firstborn son (Luke 1:34; 2:7), ${ }^{169}$ this verse may substantiate to audience members that "holy" ( $\ddot{\gamma} \gamma(0 \varsigma)$ is a characteristic of Jesus (confirmatory categorization, personal category). ${ }^{170}$ This may in turn activate the angel's utterance that Jesus is holy and the Son of God (Luke 1:35) ${ }^{171}$ and Mary's description of God's name as holy (Luke 1:49). The characteristic holy thus indicates that the relational roles of father and son embodied by God and Jesus also entail common distinguishing qualities.

When Simeon is introduced by the narrator (Luke 2:25), Simeon's social or functional group roles are not stressed, as has been the case with the other characters introduced thus far. Rather, character traits (personal categories)

\footnotetext{
165 Jesus is thus enrolled in the Jewish people and receives the sign of the covenant. Bovon, Luke, 86.

166 See also Carroll, Luke, 73-75; Levine and Witherington, Luke, 63-64.

167 See Carroll, Luke, 73-74.

168 See Carroll, Luke, 75; Levine and Witherington, Luke, 64.

169 On the idea that the firstborn belongs to God, see Bovon, Luke, 99; Carroll, Luke, 75; Levine and Witherington, Luke, 64.

170 On holy as a designation of Jesus, see also Bovon, Luke, 99.

171 See also Johnson, Luke, 54.
} 


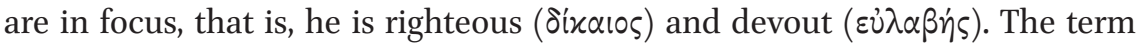
"righteous" will probably activate the characterization of Zechariah, Elizabeth, Mary, and Joseph (Luke 1:6; 2:22-24). ${ }^{172}$ Moreover, the Holy Spirit was upon him (imperfect tense). If this characteristic activates Luke 1:35, 41-45, and 67-79, audience members could contrast Simeon with Mary, Elizabeth, and Zechariah, who only on occasion are filled with the Holy Spirit. If the prophecies of Gabriel and Zechariah about John are activated (Luke 1:15-17, 76-79), audience members will see the similarities between them and infer that Simeon is a prophet (functional group role). ${ }^{173}$

Audience members learn that the Holy Spirit had made known to Simeon that he would not die before he had seen the Lord's Messiah and that the Spirit guided Simeon to the temple (Luke 2:26-27). The promise and involvement of the Holy Spirit, ${ }^{174}$ Simeon's physical interaction with baby Jesus (Luke 2:28), and his subsequent praise (Luke 2:29-32) suggest to audience members that Simeon thinks the role of the Messiah is a functional group role or social role that Jesus will subsequently embody. In Luke 2:29, functional group roles/social

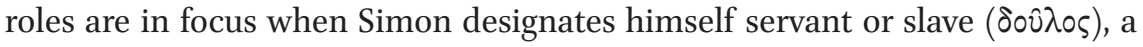
term that probably emphasizes his hierarchical relationship with the Lord

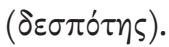

Simeon's utterance in Luke 2:30 contains the word salvation ( $\left.\sigma \omega \tau \eta^{\prime} p 10 \varsigma\right)$,

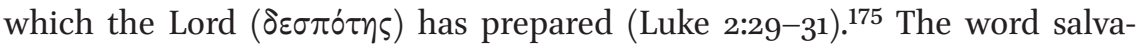
tion may prime or activate earlier utterances about God and Jesus as saviors in Luke's gospel that were possibly primed or activated by Jesus' name (Luke 2:21). ${ }^{176}$ Such activation will substantiate Jesus' future functional group role as a savior and it confirms that God's and Jesus' relational roles as father and son entail the same social functions. Simeon's utterance broadens the scope of God's salvation to include all people, Gentiles and Israel (Luke 2:31-32). ${ }^{177}$ This scope suggests that all members of the heterogeneous audience could regard Jesus as their savior. Audience members may assume that Mary and Joseph's reaction $(\theta \alpha \nu \mu \alpha \dot{\alpha} \zeta \omega)$ is a response to Simeon's praise of God and that it does not constitute a character trait (Luke 2:33). Moreover, Simeon points out to Mary that Jesus will receive contrasting responses (Luke 2:34). ${ }^{178}$

\footnotetext{
172 See also Johnson, Luke, 54; Bovon, Luke, 100; Carroll, Luke, 76; Levine and Witherington, Luke, 65 .

173 On Simeon as a prophet, see also Johnson, Luke, 55-57.

174 On Luke 1:26-27 as prophecy and fulfilment, see Bovon, Luke, 100-101.

175 This preparation is attested in Luke 1-2 (Bovon, Luke, 103).

176 On Jesus' name and task, see Carroll, Luke, 73-74.

177 See also Johnson, Luke, 57; Carroll, Luke, 78; Levine and Witherington, Luke, 65-66.

178 See also Johnson, Luke, 57; Carroll, Luke, 79-80.
} 
In contrast to Simeon, Anna is introduced by means of several roles and char-

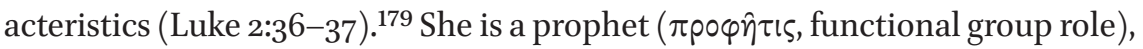
the daughter of Phanuel and a member of the tribe of Asher (social-role cate-

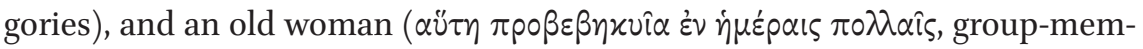
bership category). She lived with her husband (as a wife) for seven years, but after that she has been a widow (social-role categories) and is now 84 years old (confirmation of group-membership category). Based on her actions (i.e., she never leaves the temple, serves night and day with fasting and prayer [Luke 2:37]), audience members may infer that she is righteous and devout (personal categories) like Simeon and the main characters. In Luke 2:38, the narrator states that she praises God and speaks of "him," whom audience members may infer is Jesus, to all who wait for the redemption of Jerusalem. However, her utterances are merely summarized. ${ }^{180}$ Audience members could infer that her utterances correspond to the utterances of Simeon, ${ }^{181}$ which were just voiced.

Luke 2:39 once more draws attention to the fidelity of Jesus' parents to the law, ${ }^{182}$ which underscores that they are righteous (confirmatory categorization). Like the episode relating the birth and circumcision of John (Luke 1:5780 ), this episode is concluded by information about Jesus that encompasses personal categories (Luke 2:40). ${ }^{183}$ If the information about John is activated at this point, audience members will compare them. Whereas John grew and became strong in spirit (Luke 1:80), Jesus grew, became strong, and was filled with wisdom. Thus, Jesus' wisdom is emphasized. Finally, the favor of God is upon Jesus (Luke 2:40) as it is upon Mary (Luke 1:30). God's favor will probably indicate to audience members the good relationship between God and Jesus and possibly their relational roles as father and son.

\section{Construction of the Mental Character Models of Joseph, Mary, and Jesus Based on Luke 2:41-52}

The actions of Mary and Joseph in Luke 2:41-42 may once more indicate to audience members that they are righteous people (personal category,

\footnotetext{
179 On related insights, see Bovon, Luke, 105-106; Carroll, Luke, 8o-81.

180 On Anna's silence, see A.G. Serrano, "Anna's Characterization in Luke 2:36-38: A Case of Conceptual Allusion?" свQ 76 (2014): 464-480 (464).

181 For related insights, see Serrano, "Anna's Characterization," 475, 480.

182 Levine and Witherington, Luke, 69

183 See also Johnson, Luke, 56; Carroll, Luke, 82.
} 
confirmatory categorization). ${ }^{184}$ At this point, Jesus is reintroduced by the narrator as a 12-year-old who remains in Jerusalem when his parents return home. Audience members will probably not regard the parents' subsequent actions as indications of character traits, but rather as common reactions to the situation at hand, that is, they are concerned parents (Luke 2:44-48). ${ }^{185}$

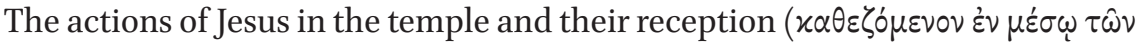

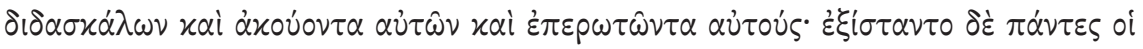

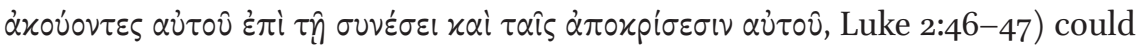
activate Luke 2:40 and thus indicate to audience members that he is wise (personal category, confirmatory categorization). ${ }^{186}$

Jesus' reaction to his mother's accusations (Luke 2:48-49) may indicate that he is surprised. ${ }^{187}$ If Jesus' utterance in Luke 2:49 activates Luke 1:35, Jesus confirms to audience members that God's supernatural intervention caused Mary's pregnancy, ${ }^{188}$ which in turn stresses his relational role as Son of God (confirmatory categorization). His parents seemingly regard Joseph as Jesus' father (Luke 2:48) 189 and thus do not understand Jesus' utterance (Luke 2:50). ${ }^{190}$ Their reaction indicates that they do not understand Jesus' double paternity, in contrast to audience members who probably have inferred that Jesus' conception was supernatural.

Based on Luke 2:43-45, audience members may infer that his parents earlier regarded Jesus as disobedient, an inference that may be corroborated by Luke $2: 48,51$. However, audience members will not necessarily share this verdict based on their knowledge of Jesus' double paternity. From now on, Jesus will play the role of obedientson (personal category). ${ }^{191}$ The information in Luke 2:52 draws attention to Jesus's wisdom (personal category, confirmatory categorization) and that he now has the favor of both God and humans (cf. Luke 2:40).192

184 See also Johnson, Luke, 6o; Bovon, Luke, 110; Carroll, Luke, 82, 84-85; Levine and Witherington, Luke, 70 .

185 His parents "are sick with worry" and have suffered on Jesus' account (Levine and Witherington, Luke, 71).

186 According to Johnson (Luke, 61), Jesus is "teaching the teachers." Levine and Witherington (Luke, 71) argue that Jesus is not a disciple, but a full participant. See also Bovon, Luke, 112.

187 See Levine and Witherington, Luke, 71.

188 For related insights, see Carroll, Luke, 82, 84, 87; Bovon; Luke,110, 113-114; Levine and Witherington, Luke, 70 .

189 See also Carroll, Luke, 86.

190 According to Johnson (Luke, 61), the incomprehension of Jesus' parents serves the literary function of showing that even faithful people do not understand.

191 For related insights, see Levine and Witherington, Luke, 72.

192 For related insights, see Levine and Witherington, Luke, 7o. 
Mary keeps all these things in her heart (Luke 2:51), which may activate Luke 2:19. In that case, audience members may infer that she still ponders. ${ }^{193}$

\section{God in the Gospel of Luke 1-2}

This analysis has explored some effects of the linear performance of Luke 1-2. Now, emphasis is on the conceptual integration that occurs after the performance of the nativity stories has ended. The composition of Luke 1-2, where different characters are faced with divine intervention in related settings, invites investigation of the effects of the interrelated character perspectives by means of conceptual blending theory. ${ }^{194}$ Due to the scope of the article, the subsequent analysis focuses on audience members' construction of mental character models of God, who, according to the narrator and prominent characters, initiates the main former, present, and future actions taking place in the Lukan world. ${ }^{195}$ Their character models of God emerge in the blended space based on projections from the input spaces constituted by the characters' perspectives.

The nativity stories primarily focus on Zechariah, Elizabeth, Mary, and Joseph. A conceptual integration network where the perspectives of these four characters constitute the input spaces therefore serves as the point of departure for audience members' constructions of mental character models of God. The main cross-space mappings that link the four input spaces are "childless" and "righteous." The generic space, which contains elements that are common to all input spaces, is constituted by these two elements. However, the input

193 See also Levine and Witherington, Luke, 72. Bennema ("Practice," 424) points out that aspects of Mary's inner life are in focus.

194 The initial character models that audience members construct of John, Jesus, and God are largely based on how the present and future roles and actions of these characters are perceived by the narrator and by human or divine characters. On the related idea that different characters or people have different insights into the meaning of Jesus, see Levine and Witherington, Luke, 62. On the parallels between John and Jesus and the way Jesus' superiority is underscored, see Tannehill, Luke-Acts, 15, 19-20, 25; J.D. Kingsbury, Conflict in Luke:Jesus, Authorities, Disciples (Minneapolis: Fortress, 1991), 37-39.

See also Kingsbury, Conflict, 37-38. The results of the analysis substantiate the idea that the interwoven stories in Luke $1-2$ constitute the beginning of Luke's story of God's work through Jesus and his precursors, associates, and successors. This position diverges from the idea that the beginning of the gospel ends in Luke 1:20, as recently argued by Cocksworth ("Zechariah and Gabriel"). She claims that the Gospel of Luke primarily is written to answer the question of Jesus' identity. As argued by Tannehill (Luke-Acts, xiii), Luke and Acts constitute a narrative unity, governed by the purpose of God. My analysis of the characters and character constellations in Luke 1-2 supports Tannehill's main thesis. 
spaces are contrasted by the different reasons why these characters are childless. The characters' childlessness, righteousness, and the reasons why they are childless are all projected to the blended space. Information about the women's unexpected pregnancies is also projected to the blended space. This composition of the elements in the blended space requires an explanation of how the couples conceive, which audience members may supply by means of their knowledge of relationships, that is, the couples have intercourse (completion). This will result in elaboration of the blend based on mundane principles. However, because the pregnancies profoundly alter the expectations associated with the women's roles as barren, old, or virgin, this may not suffice, and audience members may project the interpretations of Elizabeth and Mary to the blend as well (composition), that is, their pregnancies are the results of divine intervention (Luke 1:25, 46-55). The projection of this explanation to the blended space draws attention to God's existence and agency in the Lukan world and it will probably activate Jewish cultural memory about barren and virgin women who conceive due to divine intervention (completion). Such activation will influence how audience members run the blend (elaboration) by highlighting God's initiative and involvement.

Against the backdrop of the entire conceptual integration network, which consists of the utterances and points of view of all characters, audience members may also project the content of Gabriel's utterance in Luke 1:37 to the blended space (composition). His utterance complements the women's explanations by drawing attention to God's omnipotence. ${ }^{196}$ Projections to the blended space from these three input spaces thus suggest that omnipotence constitutes a main character trait of God. God's omnipotence may in turn prime or activate further traditions pertaining to God's mighty acts in Jewish cultural memory (completion), which will further influence how the blend is run.

The entire conceptual integration network constituted by the perspectives of the various characters (input spaces) who praise God in response to divine interventions (generic space) introduces further, interrelated traits and roles that audience members may project to the blended space to expand on the character model of God. The names of John and Jesus, God's initiatives regarding their conception, and their future roles prompt audience members to project one important character trait and one functional group role to the blended space. John's name underscores that God is merciful (Luke 1:13) and this character trait is also indicated by Mary, (Luke 1:50), Zechariah (Luke 1:72),

196 Gabriel's status as a divine being indicates that his utterance may constitute an interpretative key to the nativity stories, and possibly to Luke-Acts. 
and the neighbors and relatives of Elizabeth (Luke 1:58).Jesus' name (Luke 1:31) rather draws attention to God's functional group role as a savior, a role which is also mentioned by Mary (Luke 1:47) and Zechariah (Luke 1:69-71). This role is interrelated with God's roles as redeemer (Luke 1:68) and deliverer (Luke 1:73).

In the blend, God's mercy and roles as savior, redeemer, and deliverer may prime or activate God's interventions in the past. The process of completion thus enables audience members to relate the current information about God to Jewish cultural memory. Thus, the past events are integrated with God's interventions in the current lives of the main characters for the future good of his people, as suggested by Mary (Luke 1:46-55) and Zechariah (Luke 1:68-79). The activation of traditions constituting Jewish cultural memory enables audience members to fill in gaps (completion) and elaborate the blend in different ways, depending on the traditions they recall. Because the events in Luke 1-2 will primarily prime and activate events that are in keeping with the nativity stories, audience members will perceive a high degree of continuity between God's past, present, and future salvific acts. ${ }^{197}$

Projection of elements from the input spaces of Jesus and John to the blended space, that is, Jesus as savior and John as the precursor of the Lord (Jesus or God, depending on audience members' previous knowledge), introduces a new approach to salvation to the blended space. The rest of the gospel and Acts provide information that will enable audience members to elaborate on how this salvation will be effected.

Because the main Lukan characters are described as righteous, prophets, and even divine, audience members will probably regard their utterances about God as reliable. ${ }^{198}$ This point is underscored by the fact that the characters are in unison. The characters and their overlapping worldviews in the Lukan nativity stories thus lay a reliable, solid foundation for the narrative about God's future salvific actions for his people through his representatives (i.e., John, Jesus, and their successors) in Luke-Acts. Because God is presented as omnipotent, audience members may consider his chances of success to be high and if they simulate the plot based on identification with either of the characters portrayed in these stories, they may, like these characters, experience positive emotions of happiness or joy. Such simulation may convince them to regard the nativity stories as good news.

197 Stories about the covenant may constitute one example of traditions that are activated or primed during the performance of Luke 1-2 (circumcisions of John and Jesus, similarities between Elizabeth and the barren matriarchs, Luke 1:72-75).

198 On these characters as "reliable spokespersons for God," see also Tannehill, Luke-Acts, 22. 


\section{Conclusion}

This article has shown how a cognitive narratological analysis of Lukan characters moves beyond classification of characters and emphasis on either mimetic or synthetic aspects by exploring how characters are constructed when the discourse aspect and the mental states and processes of interpreters intertwine. The first part of the analysis focused on (1) textual cues indicating character traits, literary schemata, and social schemata that enable audience members to process characters as real people and (2) how different emotions are elicited in audience members based on simulation of the plot from the perspectives of the characters. The second part of the analysis emphasized how different perspectives on God are projected to the blended space, resulting in the construction of a mental character model of this character. Conceptual blending theory thus demonstrates how analysis of character constellations can move beyond the structuralist binary of similarity versus difference. In fact, the blended space facilitates composition, where elements constituting different perspectives are combined, which in turn recruits structures from the memory of audience members, including Jewish cultural memory (completion). As a result, the analysis does not merely point out intertextual relationships: Intertextual blending facilitates both the exploration of how God's past, present, and future salvific interventions are integrated and the creation of a coherent and enduring mental character model of God. Based on the information audience members project to the blended space and the ensuing processes of composition and completion, the heterogeneous audience can simulate God's salvific acts in different ways and thus explore different outcomes. In sum, the cognitive approaches employed in this article go beyond the text-centered, formalist, ahistorical, and universalistic tendencies of classical narratology by demonstrating how textual features (discourse aspect) interact with different types of text-external knowledge (suggestion aspect), resulting in different interpretations. 